\title{
Movimento negro e educação
}

\author{
Luiz Alberto Oliveira Gonçalves
}

Faculdade de Educação da U niversidade Federal de Minas Gerais

\section{Petronilha Beatriz Gonçalves e Silva}

Faculdade de Educação da U niversidade Federal de São Carlos

O nosso grito vive nos fatos e nós advogamos os direitos da raça negra, porque ela tem uma grande herança dentro do Brasil.

Manchete de o Clarim d'Alvorada, 1931

Todas as vezes que se inicia qualquer reflexão sobre a escolarização dos negros no Brasil, o ponto de partida é o irremediável lugar-comum da denúncia. Em outros termos, o presente, com todas as suas injustiças e mazelas, se afigura como única dimensão histórica do problema. O passado, quando aparece, serve apenas para confirmar tudo aquilo que o presente nos comunica tão vivamente.

Olhando para o passado recente das denúncias concernentes ao estado de precariedade da escolarização dos negros brasileiros, encontramos os seguintes tipos de registro: a) produções acadêmicas voltadas exclusivamente para os problemas atuais da educação dos negros; b) relatórios resultantes de encontros regionais do movimento negro, dando atenção especial aos problemas da educação; e c) depoimentos de antigos militantes que combateram a discriminação racial em nossa sociedade, nos anos 20 e 30, e nos anos 50, falando do significado da educação para si e para a população negra em geral.

Embora cada um desses registros expresse épocas diferentes e, neles, os sujeitos falem de lugares sociais diversos, o objeto de que tratam é a educação dos negros e seus múltiplos significados. Criticam o status quo, e esta crítica tem contribuído para denunciar a falácia da igualdade de oportunidades para todos, que se supunha existir em nossa pujante civilização tropical. Em outros termos, o forte apelo ao presente que podemos encontrar nesses registros tem representado, tanto no meio acadêmico quanto no interior dos movimentos negros (do presente e do passado), uma reação aberta contra o mito da democracia racial.

Pretendemos, no presente artigo, propor uma outra leitura do problema: interrogar o passado. Sugerir hipóteses de como a situação educacional dos negros poderia ter evoluído caso algumas estratégias tivessem sido adotadas pelas políticas educacionais. Entendemos que há pontos de nosso passado que podem muito bem esclarecer as origens de graves problemas educacionais que afligem o grosso da comunidade negra brasileira. 
Problemas tão profundos que o século XX, inteiro, com tudo que representou em termos de avanço tecnológico, não foi suficiente para solucioná-los. Ao contrário, neste século, criaram-se desigualdades imensas.

Quando relemos as críticas lançadas à atual situação educacional dos negros brasileiros, encontramos dois eixos sobre os quais elas foram estruturadas: exclusão e abandono. Tanto uma quanto o outro têm origem longínqua em nossa história.

Ambos aparecem em obras que tratam da história da educação, em especial naquelas que buscam estudar como as elites brasileiras tentaram equacionar o problema da instrução das camadas populares (Gonçalves, 2000).

Tal preocupação teve amplo espaço no século XIX, período em que a construção de uma nação se colocava para as elites como uma questão crucial. Sabia-se que seria impossível erigir uma nação sem que, paralelamente, se desenvolvessem estratégias que pudessem fortalecer a instrução pública nas diferentes províncias do Império (Moacyr, 1939).

Era preciso que toda a população passasse a ter acesso às letras, o que não se julgara necessário durante o período colonial, quando, como acentua Nascimento (1940, p. 220) "se proibia o alfabeto nas casas grandes", inclusive a "descendentes dos fidalgos e dos afortunados portugueses". Sobretudo os africanos escravizados estavam impedidos de aprender a ler e escrever, de cursar escolas quando estas existiam, embora a alguns fosse concedido, a alto preço, o privilégio, se fossem escravos em fazendas de padres jesuítas. Estes, visando a "elevação moral" de seus escravos, providenciavam escolas, para que os filhos dos escravizados recebessem lições de catecismo e aprendessem as primeiras letras, sendo-lhes impedido, entretanto, almejar estudos de instrução média e superior. Nessas escolas dos jesuítas, as crianças negras eram submetidas a "um processo de aculturação, gerada pela visão cristã de mundo, organizada por um método pedagógico" de caráter repressivo que visava a "modelagem da moral cotidiana, do comportamento social" (Ferreira \& Bittar, 2000).

Como se pode ver, alguns casos da escolarização de escravos em mãos de jesuítas se devem muito mais à necessidade de submetê-los a um rígido controle de seus senhores missionários do que a um projeto com vistas a mudar o destino dos cativos.

Com o intuito de divulgar ao mundo, o quanto, no Brasil, se davam "provas e amor ao progresso e à perseverança na trilha da civilização”, José Ricardo Pires de Almeida publica, no ano de 1889, em língua francesa, obra sobre história e legislação da instrução pública no Brasil, entre os anos de 1500 e 1889. Tendo destacado que, no Império brasileiro, se assimilara o que havia "de mais completo nas nações avançadas da Europa, adaptando a seu gênio nacional" e buscando salientar papel de liderança do Brasil na América Latina, o autor aponta que, em 1886, numa população de 14 milhões de habitantes, 248.396 eram alunos de estabelecimento de ensino. E sugere, salvo melhor juízo, não ser esta cifra maior por estarem incluídos no cômputo do total da população "os indígenas e os trabalhadores rurais de raça" (Almeida, 2000, p. 17-18).

Em outros termos, índios e negros são, assim, considerados um enorme entrave à modernidade do país. Como nos lembra Sidney Chalhoub, esta era uma idéia poderosa, "postulada de forma aparentemente consensual pela classe proprietária na segunda metade do século XIX” (Chalhoub, 1988, p.103).

Ainda que Almeida não precise o contingente de negros freqüentando os ditos estabelecimentos de ensino, ele nos assegura que existiam "300 asilos, distribuídos por diferentes províncias, para crianças abandonadas" (Almeida, 2000, p. 18), que certamente abrigavam significativo número de crianças negras.

Vários estudos já mostraram que uma das estratégias de instrução pública, no século XIX, foi a de preparar adultos para novas modalidades de trabalho que começavam a ser introduzidas (Paiva, 1987; Beisiegel, 1974). Examinando o significado dos cursos noturnos no contexto da educação brasileira, Eliane Teresinha Peres produz uma síntese muito esclarecedora do papel desses cursos no final do século XIX (Peres, 1995). Em geral, a instrução era associada ao trabalho, e ambos eram descritos como atividades indispensáveis a qualquer povo que pretendesse progredir ou criar uma civilização. Eram os antídotos mais eficazes contra o crime e o vício. Ambos (instrução e trabalho) estruturavam um tipo de discurso moralista dirigido às classes populares. 
Segundo a autora, "os cursos noturnos para jovens e adultos foram projetados e se expandiram em todo país" para atender os seguintes objetivos: o "da civilidade, da moralidade, da liberdade, do progresso, da modernidade, da formação da nacionalidade brasileira, da positividade do trabalho" (idem, p. 95).

O Decreto de Leôncio de Carvalho, de 1878, cria os cursos noturnos para livres e libertos no município da Corte. Segundo Peres, o referido Decreto estabeleceu normas de validade nacional, inspirando várias províncias na criação de seus cursos noturnos (idem, p. 98).

Tendo como público alvo o indivíduo livre e liberto, pode-se inferir que, desde sua origem, as escolas noturnas eram vetadas aos escravos. Tal veto caiu, em abril de 1879, um ano após a criação dos cursos de jovens e adultos, com a Reforma do Ensino primário e secundário apresentada pelo próprio Leôncio de Carvalho. Alguns estudos registram que, em algumas províncias, escravos freqüentavam as escolas noturnas (Beisiegel, 1974; Paiva, 1987). Já em outras, como a de São Pedro do Rio Grande do Sul, vetava-se completamente a presença dos escravos e dos negros libertos e livres (Peres, 1995, p. 101).

O Estado não foi o único provedor de escolas noturnas. Associações particulares, de caráter literário e/ ou político, mantiveram suas próprias escolas. Por vezes, serviram de espaço de propaganda política, buscando aliciar os negros em prol da causa abolicionista e republicana (idem).

Em suma, as escolas noturnas representaram, no período em questão, uma estratégia de desenvolvimento da instrução pública, tendo em seu bojo poderosos mecanismos de exclusão, baseados em critérios de classe (excluíam-se abertamente os cativos) e de raça (excluíam-se também os negros em geral, mesmo que fossem livres e libertos). Ainda que amparadas por uma reforma de ensino, que lhes dava a possibilidade de oferecer instrução ao povo, essas escolas tinham de enfrentar o paradoxo de serem legalmente abertas a todos em um contexto escravocrata, por definição, excludente.

Na seqüência, vejamos como os eixos "exclusão e abandono" se entrecruzam, quando examinamos, em detalhe, a questão das crianças beneficiadas pela Lei do Ventre Livre de 28, de setembro de 1871. Crianças nas- cidas de mulheres escravas, a partir dessa data, eram livres e deviam ser educadas.

Em instigante trabalho sobre a educação de crianças, nas duas décadas que antecederam a Abolição, Marcus Vinicius Fonseca desenvolve o argumento segundo o qual, no referido período, surgiram, no próprio escalão do governo imperial, idéias que preconizavam a educação dos libertos como uma medida complementar e necessária à própria Abolição (Fonseca, 2000).

Segundo o autor, essas idéias foram defendidas por célebres personagens do Império. Dentre eles, Fonseca destacou o escritor José de Alencar, o indianista, à época deputado e ferrenho adversário da Lei do Ventre Livre. Recusava-se a aceitar a idéia de libertar o cativo antes que este fosse educado ou, para usar suas próprias palavras, "fosse redimido da ignorância, do vício, da miséria e da animalidade" (Alencar apud Fonseca, 2000, p. 36).

Outro defensor da idéia de uma educação que preparasse os cativos para a liberdade foi o não menos célebre historiador e jurisconsulto Perdigão Malheiros. Atento aos escritos do arguto doutrinador do império, Fonseca nos chama a atenção para uma passagem muito importante da obra Escravidão no Brasil, na qual Perdigão Malheiros preconiza o tipo de educação que, segundo ele, prepararia os escravos para a liberdade (idem, p. 32). Na essência, deveria ser uma "educação moral e religiosa", sem se descuidar, é claro, de "uma educação profissional", que garantisse aos libertos um ofício do qual pudessem "manter a si e a família, caso a tivessem” (Perdigão Malheiros, 1837). Mas, afinal de contas, quem se ocuparia da educação dessas crianças?

A resposta a esta questão apareceu inicialmente em um projeto de lei, em 1870, segundo o qual ficavam os senhores de escravos obrigados a criar e a tratar as crianças nascidas de mães escravas, devendo oferecer-lhes, sempre que possível, instrução elementar. Em contrapartida, os libertos permaneciam em poder e sob a autoridade dos proprietários de suas mães. ${ }^{1}$ Embora o referido projeto de lei conservasse o direito de propriedade

${ }^{1}$ Congresso. Câmara dos Deputados. Elemento Servil: parecer e projeto de lei apresentado à Câmara dos Deputados em 1870. Rio de Janeiro: Typographia Nacional, 1874, p. 27. 
dos senhores de escravos, ele produziu muita animosidade, pois feria frontalmente seus princípios morais, uma vez que a educação concedida aos escravos poderia representar uma mudança efetiva na condição dos sujeitos emancipados do cativeiro (Fonseca, 2000, p. 39).

Fonseca sugere que o descontentamento dos senhores de escravo era tão grande que ameaçava a aprovação da Lei do Ventre Livre; o que levou a um complexo processo de negociação entre parlamentares e proprietários, desembocando, em setembro de 1871, na lei $\mathrm{n}^{\circ}$ 2.040. Esta isentava os senhores de "qualquer responsabilidade quanto à instrução das crianças nascidas livres de mulheres escravas" (idem, p. 40).

Educadas seriam apenas aquelas que fossem entregues pelos proprietários ao governo, mediante indenização em dinheiro. Diz o texto da lei que "o governo poderá entregar a associações por ele autorizadas os filhos das escravas, nascidos desde a data desta lei, que sejam cedidos ou abandonados pelos senhores delas, ou tirados de poder destes em virtude [...] de maus tratos"2. $\mathrm{Na}$ falta dessas associações ou estabelecimentos criados para tal fim, essas crianças seriam enviadas a pessoas designadas pelos Juízes de Órfãos, que se encarregariam de sua educação.

Foi, portanto, no calor desse debate, que o governo, através do Ministério da Agricultura, passou a destinar recursos a estabelecimentos públicos com o intuito de atender à educação dos ingênuos e libertos. Tal iniciativa, como nos mostra Fonseca, começa a vigorar a partir de 1872, ou seja, um ano após a promulgação da Lei do Ventre Livre (idem, p. 53). Além da capital, seis províncias acolheram os estabelecimentos supracitados: Piauí, Pernambuco, Goiás, Minas Gerais, Ceará e Pará (idem, p. 155).

Dito isso, vale ressaltar o que nos interessa no presente artigo, a saber: em que resultou essa política engendrada pelo Ministério da Agricultura? Os documentos e os estudos nos mostram que os proprietários de escravos não entregaram as crianças ao Estado, tampouco as educaram.

${ }^{2}$ Actos do Poder Legislativo, Lei $\mathrm{n}^{\mathrm{o}} 2.040$, de 28 de setembro de 1871. In: Leis do Brasil. Rio de Janeiro: Imprensa Oficial, 1871, p. $147-149$.
O registro de matrículas de crianças beneficiadas pela Lei do Ventre Livre, entre 1871 e 1885, apresentado no relatório do Ministério da Agricultura de 1885, revela que, na capital e nas 19 províncias, o contingente de matriculados chegava a 403.827 crianças de ambos os sexos. Destes, apenas 113 foram entregues ao Estado mediante indenização no mesmo período (Quadro de Matrícula dos Filhos Livres de Mulher Escrava (apud Fonseca, 2000, p. 77).

Quando nos interrogamos acerca do abandono a que foi relegada a população negra brasileira no que se refere à educação escolar, não podemos deixar de considerar os dados supracitados. Por parte do Estado, houve, na segunda metade do século XIX, uma iniciativa concreta que, se correspondida à altura, poderia ter mudado a condição educacional na qual os negros ingressaram no século XX.

Trata-se de uma hipótese, é claro. Não há de nossa parte intenção de reconstruir uma história que não existiu, mas sim de explicitar alguns aspectos que nos ajudem a entender por que, apesar de existir uma lei garantindo a educação das crianças negras e livres, estas foram consentidamente excluídas dos processos de escolarização. De certa forma, o Estado assistiu passivamente à precarização moral e educacional do referido contingente.

Parte da resposta a esta questão, pode ser encontrada na própria Lei do Ventre Livre. No item 1 de seu

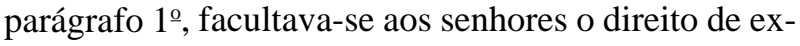
plorar o trabalho das crianças libertas até a idade de 21 anos. Ficou patente que foi exatamente isto que eles fizeram em larga escala. Tal atitude pode ser interpretada como mais um dos paradoxos gerados no interior de uma sociedade escravocrata. Analisando este paradoxo, Kátia Mattoso nos mostra que nada mudou na vida dos libertos, pois, segundo ela, foram jogados novamente na escravidão (Mattoso, 1988), ainda que o tipo de vínculo com o senhor mudasse, deixasse de ser o de escravo e passasse a ser, por exemplo, o de tutelado.

Instituíra-se a tutela, pondera Rizzoli (1995, p. 25), como forma de "assegurar ao menor, juridicamente incapaz, os seus direitos, bem como as condições para o seu desenvolvimento físico e intelectual". Sob a alegação de poder oferecer "condições materiais necessárias à prestação da tutela", antigos senhores pleiteavam a 
adoção de crianças e jovens, filhos de escravos ou de libertos, órfãos, com a justificativa de que os pais, quase sempre as mães não possuíam bens, não tinham "condições de zelar por seus filhos e educá-los” (Rizzoli, 1995, p. 290). A análise das razões apontadas para requerer nomeação de tutor, em autos do Cartório do $1^{\circ}$ Ofício da Comarca de São Carlos/SP, lavrados entre 1877 e 1897, leva-nos a considerar a tutela como "forma velada de apropriação do trabalho do menor, sobretudo das meninas, transformando-as em empregadas domésticas" (idem, p. 25).

A esse respeito, podemos concluir com Fonseca que ter deixado as crianças negras e livres em poder dos senhores foi condená-las a "receber o mesmo tratamento dispensado aos escravos e, conseqüentemente, a mesma educação". Ou seja, aquela educação que se guiava pelo chicote (Fonseca, 2000, p. 37),

Entre a lei e a realidade do filho da escrava, havia um fosso enorme. Como nos ensina Kátia Mattoso, a lei pretendia amparar uma “criança cuja mãe biológica era frequientemente ausente sendo criada sem referências parentais seguras" (Mattoso, 1988, p. 48). Poderia ter como pais o proprietário de sua mãe, ou então um outro escravo, que nunca chegaria conhecer por ter sido vendido a um outro senhor. E ainda, o filho da escrava era uma criança que poderia conviver com "irmãos de cores diferentes", como também "com irmãos de status diferentes, que, legalmente, podiam tornar-se seus senhores" (idem, p. 51).

Embora as questões referentes às crianças negras, no período em consideração, tenham uma especificidade incontestável, elas não se desvinculam dos problemas relativos à infância desamparada, como um todo.

Não é por acaso que muitos autores não distinguem os dois temas em seus respectivos estudos. Maria Lúcia Mott e outros mostram que, no Rio de Janeiro, após a Lei do Ventre Livre, houve aumento significativo de crianças pardas e negras enjeitadas e entregues à Casa dos Expostos. Segundo os autores, o índice de abandono dobrou, no caso dos pardos, e triplicou, no caso dos negros, após a promulgação da citada lei. A hipótese aventada por eles é de que seria mais vantajoso para os proprietários "abandonarem os filhos de suas escravas na Casa dos Expostos”, e assim poder alugá-las como amas- de-leite, o que "lhes permitia auferir" uma renda muito mais opulenta do que "a oferecida pelo governo em troca de concessão dos ingênuos” (Mott et al., 1988, p. 23).

Maria Luiza Marcillio, estudando o mesmo período, nos oferece um relato muito interessante acerca das instituições filantrópicas laicas ou confessionais que, no final do século XIX, se associaram para cuidar de jovens delinqüientes e crianças abandonadas. Neste contexto, incluem-se as crianças negras, as quais se enquadram nos motivos que levaram a aumentar o índice de abandono, no período supracitado, largamente explorado pela autora (Marcillio, 1997).

Quando saímos do século XIX e adentramos o século XX, deparamo-nos com o abandono a que foi relegada a população negra. A maior parte dos estudos retrata a situação dos negros nas áreas urbanas, no período em que algumas cidades do país iniciam rápido processo de modernização. Mudanças bruscas de valores, associadas a profundas transformações no mercado de trabalho, exigiam, da parte dos diferentes segmentos sociais, a criação de novas formas organizacionais, por adoção de novos dispositivos psicossociais, que os ajudassem a se inserir na sociedade moderna.

Não há necessidade de nos alongar sobre o assunto, uma vez que vários autores já estudaram o processo de secularização das cidades brasileiras no início do século $\mathrm{XX}{ }^{3}$

Para o desenvolvimento do presente artigo, basta destacar o fato de que foi nesse contexto de mudanças sociais, favorecedor de estratégias de mobilidade social, que emergiram os primeiros movimentos de protestos dos negros com o formato de um ator coletivo moderno, que se constrói na cena política, lutando contra as formas de dominação social (Fernandes, 1986).

Organizações de protesto dos negros surgiram, em diferentes regiões do país. Textos e depoimentos de exmilitantes mostram a existência de entidades de defesa da raça negra já no início de nossa história republicana. Entretanto, devemos reconhecer que o poder de mobili-

\footnotetext{
${ }^{3}$ Sobre o assunto, os estudos de Roger Bastide, Florestan
} Fernandes, Clóvis Moura, Guerreiro Ramos, dentre outros, continuam sendo importantes referências, sobretudo no que tange às relações entre negros e brancos. 
zação dessas organizações teve, de fato, visibilidade nas capitais e nas grandes cidades brasileiras. Ao contrário do que já se escreveu sobre a convivência pacífica das raças no Brasil, as relações entre elas eram, no quotidiano, marcadas por conflitos e tensões (Chalhoub, 1988; Fernandes, 1986; Schwarcz, 1987; Azevedo, 1993).

Essa tendência foi mantida praticamente ao longo de todo o século XX. Em momentos cruciais da história republicana, podemos encontrar registros dos movimentos de protesto dos negros: o mais emblemático foi o promovido pela Frente Negra Brasileira, em 1931, na cidade de São Paulo, mobilizando em torno de 100.000 militantes (Moura, 1983). Na cidade do Rio, o protesto racial se organizou em torno do Teatro Experimental do Negro, liderado por Abdias do Nascimento e Guerreiro Ramos, mas isto já no final dos anos 40 . Teve um papel muito importante na discussão referente à nova carta constitucional, em 1946, com a derrocada da ditadura varguista (Gonçalves, 1997). Já nos anos 80, o movimento tem um caráter nacional, reúne entidades negras de todo o país em defesa da democracia (Nascimento, 1989; Gonçalves, 1997).

As organizações desempenham vários papéis no interior da população negra. São pólos de agregação que podem funcionar como clubes recreativos e associações culturais (grupos que preservam valores afro-brasileiros), ou como entidades de cunho político, ou, mais recentemente, como formas de mobilização de jovens em torno de movimentos artísticos com forte conteúdo étnico (hip-hop, blocos afros, funk e outros). Em muitos casos elas se configuram como instâncias educativas, na medida em que os sujeitos que participam delas as transformam em espaços de educação política.

Já no início do século XX, o movimento criou suas próprias organizações, conhecidas como entidades ou sociedades negras, cujo objetivo era aumentar sua capacidade de ação na sociedade para combater a discriminação racial e criar mecanismos de valorização da raça negra.

Dentre as bandeiras de luta, destaca-se o direito à educação. Esta esteve sempre presente na agenda desses movimentos, embora concebida com significados diferentes: "ora vista como estratégia capaz de equiparar os negros aos brancos, dando-lhes oportunidades iguais no mercado de trabalho; ora como veículo de as- censão social e por conseguinte de integração; ora como instrumento de conscientização por meio da qual os negros aprenderiam a história de seus ancestrais, os valores e a cultura de seu povo, podendo a partir deles reivindicar direitos sociais e políticos, direito à diferença e respeito humano" (Gonçalves, 2000, p. 337).

Para melhor compreender esses sentidos dados à educação, passemos ao exame dos contextos nos quais foram elaborados.

Conforme já dissemos, a herança do passado escravista, no início do século XX, marca profundamente as experiências da população negra no que se refere à educação.

Segundo alguns autores, naquele momento as crianças negras estavam afastadas dos bancos escolares. Desde a tenra idade eram levadas a atividades remuneradas, para auxiliar na manutenção da família. Sua formação para o trabalho era feita sob a orientação dos patrões, no desempenho das mais variadas tarefas (Silva, 1987).

Veja-se, por exemplo, como um dos líderes do movimento negro dos anos 20, em São Paulo, fala de sua experiência de criança afastada da escola e lançada no mercado de trabalho precocemente. Nascido em 1900, Correia Leite lembra dos seguintes eventos de sua infância: "minha mãe foi uma negra, doméstica, muito lutadora, mas não podia me manter. Ela tinha de me deixar na casa dos outros para poder trabalhar [...] eu sempre vivi maltratado [...] tive uma irmã que veio mais tarde e viveu a mesma circunstância que a minha [...] com ajuda de minha mãe fui trabalhar como entregador de marmitas, menino de recados e ajudante de carpinteiro" (Cuti \& Correia Leite, 1992, p. 23).

Mais tarde, já adolescente, lembra o militante Correia Leite: “...eu arrumei um emprego com um italiano [...] de ajudante de lenheiro e fazendo trabalho de cocheiro [...] Eu trabalhava com o italiano pra ganhar dez mil-réis por mês, casa e comida. Depois os italianos começaram a gostar de mim [...] Então começou também a me utilizar para tomar conta de crianças e fazer pequenos serviços nos dias em que não trabalhava com o velho italiano" (idem, p. 25).

A escolarização, entre os homens negros nascidos no início do século XX, quando ocorreu, foi, em sua maioria, na idade adulta (Silva, 1987, p. 12). 
Já as mulheres eram encaminhadas a orfanatos, onde recebiam preparo para trabalhar como empregada doméstica ou como costureira. Famílias abastadas as adotavam, quando adolescentes, como filhas de criação, o que de fato significava empregadas domésticas não remuneradas (idem). Este fato acabou, de certa forma, estigmatizando o lugar da mulher negra no mercado de trabalho.

Para alguns intérpretes de situações dos negros no final dos anos 20, o lugar destinado à mulher negra amenizava um grave problema social, à época, o desemprego no meio negro. Veja-se, por exemplo, como um outro líder do movimento negro paulista, Francisco Lucrécio, descreve a situação das mulheres negras, no período em consideração: "A maior parte das mulheres era que arcava com as despesas da família, porque eram importantes na época as empregadas domésticas, principalmente as negras, pois elas sabiam lidar com a cozinha, com a limpeza e elas encontravam emprego mais facilmente que os homens" (Barbosa, 1998, p. 37).

Pelos exemplos acima pode parecer que o mundo do trabalho, ou mais precisamente, a necessidade de trabalhar, afastava tanto os homens negros quanto as mulheres negras da escola. Em parte isto era verdade, entretanto, entidades negras não se acomodaram diante da situação. Combateram o analfabetismo e incentivavam os negros a se educarem.

Em seu denso estudo sobre as lutas dos movimentos negros paulistas na primeira metade do século XX, Regina Pahim Pinto dedica uma seção ao exame de como o movimento acentuava a educação como instrumento de ascensão social (Pinto, 1994). Iniciativas educacionais surgiram das próprias entidades. No dizer da autora, os negros desenvolviam por meio de suas organizações de luta uma "percepção bastante crítica e negativa sobre a política educacional, ou melhor, sobre a ausência de qualquer providência [...] por parte das autoridades constituídas" (idem, p. 238).

Foram as entidades negras que, na ausência dessas políticas, passaram a oferecer escolas visando a alfabetizar os adultos e promover uma formação mais completa para as crianças negras.

Entretanto, um outro estudioso das lutas contra o racismo no Brasil, Clóvis Moura, entendeu esse movi- mento como algo que se realizava exclusivamente na esfera privada. Para ele, os negros não tinham a dimensão pública da educação, uma vez que, quando a ela se referiam, viam-na como uma questão da família e não do Estado (Moura, s/d.).

Embora com pontos de vista tão opostos, vale ressaltar que as fontes históricas sobre as quais Moura e Pinto se apóiam para examinar a quem os negros atribuíam a responsabilidade da educação, foram os jornais negros da época, ou seja, a imprensa negra do início do século.

Nos jornais da imprensa negra paulista do começo do século, no período fecundo de sua divulgação, que vai dos anos 20 ao final dos anos 30, encontram-se artigos que incentivam o estudo, salientam a importância de instrumentar-se para o trabalho, divulgam escolas ligadas a entidades negras, dando-se destaque àquelas mantidas por professores negros. Encontram-se mensagens contendo exortações aos pais para que encaminhem seus filhos à escola e aos adultos para que completem ou iniciem cursos, sobretudo os de alfabetização. O saber ler e escrever é visto como condição para ascensão social, ou seja, para encontrar uma situação econômica estável, e, ainda, para ler e interpretar leis e assim poder fazer valer seus direitos.

Um dos colaboradores dessa imprensa, Antunes $\mathrm{Cu}$ nha, avalia que o jornalismo negro, real instrumento de luta dos afrodescendentes na primeira metade do século XX, tenha se constituído em "fator importante na educação e desenvolvimento do povo negro" (Cunha, 2000).

O tom era militante e combativo. Os jornais negros buscavam tocar a comunidade negra no âmago. Por vezes a linguagem era de tal forma contundente que funcionava como uma espécie de crítica aos comportamentos no meio negro, considerados negativos à causa negra.

Tinham os editores dos jornais negros, bem como outros militantes da época, o entendimento de que a libertação trazida pela lei de 1888 , para se consolidar, exigia que todos fossem educados, isto é, freqüentassem os bancos escolares.

Antes de passarmos ao exame dessas fontes, gostaríamos de expressar nossa preocupação quanto às formas de tratar a imprensa negra da época. Embora importante no que se refere à difusão de novas idéias, ela 
tinha um espaço de circulação limitado. Não se pode esquecer que ela se veiculava entre os poucos que eram alfabetizados na população negra brasileira. Ou seja, não se destinava à massa mas àqueles que tinham em seus currículos uma história, pequena que fosse, de escolarização (Gonçalves, 1997). Entretanto, junto a muitos desses reunia-se "gente sem estudo para ouvir as notícias". "Avó, pai sem leitura, comprava o jornal, para que os netos, os filhos lessem para eles", conta Antunes Cunha (2000).

Alguns jornais circulavam na época na cidade de São Paulo: O Alfinete, O Kosmos, A Voz da Raça, o Clarim d'Alvorada e outros. Em geral, eram ligados a entidades ou constituíam eles mesmos uma entidade autônoma, como foi o caso do Clarim d'Alvorada, veículo pelo qual o militante Correia Leite, entre outros, fez passar suas idéias sobre o destino da raça negra.

Como se dirigiam a um grupo que se distinguia no interior da comunidade negra, ou seja, um grupo do qual poderiam emergir lideranças, os jornais não poupavam críticas ao comportamento da maioria da comunidade. Por exemplo, atribuíam, às vezes, aos próprios negros a responsabilidade pela precária situação educacional da comunidade negra.

Em um de seus artigos, publicado em 1926, O Clarim d'Alvorada não via justificativa para os negros não estudarem. Para o redator, "escolas há em todos os bairros, nocturnas, diurnas, gratuitas, mantidas pelo nosso governo, por associações diversas". Só que nessas escolas encontram-se alunos de todas as nacionalidades, "mas de côr, não sei qual a razão de se contar as dezenas" (O Clarim d'Alvorada, 24/10/1926, p. 2).

Ainda no mesmo artigo, fala-se de associações negras que "para facilitar crearam cursos elementares para os filhos dos seus associados e de todos que desejassem receber os primeiros conhecimentos de instrução" (idem). Entretanto, essas iniciativas não eram bem sucedidas, ou seja, os pais tanto não iam como não encaminhavam seus filhos às aulas.

Como se pode ver, O Clarim d'Alvorada responsabiliza a família e, às vezes, o próprio negro pela precariedade educacional.

É preciso entender essas críticas dentro do contexto da época. Lembre-se de que, em páginas anteriores, mostramos a malsucedida experiência dos orfanatos criados pelo Ministério da Agricultura para educar as crianças negras, "beneficiadas" pela Lei do Ventre Livre. Fizemos questão de registrar que das 403.827 crianças nascidas no período entre 1871 e 1885 , apenas 113 foram encaminhadas aos estabelecimentos de ensino, ou seja, $0,02 \%$, o que significa dizer que a maioria esmagadora entrou no século XX com um déficit educacional gigantesco. É, portanto, tendo em vista este quadro, que devemos compreender por que a imprensa negra dirigia sua crítica não para a falência da política pública, mas sim para o "esmorecimento" da própria população negra. Tratava-se de uma estratégia que, para aumentar o índice de escolarização da população negra, via como importante ponto de partida incutir nos indivíduos a idéia de que a educação é um capital cultural de que os negros precisavam para enfrentar a competição com os brancos, principalmente com os estrangeiros.

Era com esse intuito que o próprio $O$ Clarim d'Alvorada, em um outro artigo publicado em 1929, exorta a mocidade negra. Neste caso, o redator foi o militante Correia Leite. Ele compara os jovens negros com "os jovens filhos dos italianos e de outras nacionalidades". Assinala que, enquanto os primeiros não eram incentivados para seguir os estudos e raramente eram vistos "com livros debaixo dos braços vindo das tantas escolas noturnas", os segundos não só eram estimulados a frequientar as escolas profissionais como de lá já eram encaminhados para "os escriptorios commerciaes, bancos e etc" (Correia Leite, Mocidade Negra, O Clarim d'Alvorada, 09/06/1929, p. 4).

Em 1930, Antunes Cunha buscava, no mesmo Clarim d'Alvorada, persuadir seus co-irmãos das razões e necessidades para ações que os afirmassem enquanto pessoas e cidadãos: "o negro madrugou nos alicerces da formação brasileira e se acha na vanguarda para as horas de angústia e sacrifícios e é esquecido nas horas de regozijo [...] precisamos trabalhar com astúcia para o complemento de nossa emancipação, em que os princípios estão baseados no momento atual” (p. 1).

Como dito anteriormente, por intermédio dos jornais negros da época, têm-se informações importantes quanto à existência de escolas mantidas exclusivamente pelas entidades negras, sem qualquer subvenção do Estado. 
Regina Pahim Pinto, em seu trabalho, nos chama a atenção para o fato de que a primeira referência à atividade educacional para os negros aparece, na cidade de São Paulo, no jornal O Propugnador, em 6 de outubro de 1907. O texto informava sobre "aulas oferecidas, no curso diurno e noturno da Irmandade de Nossa Senhora do Rosário" (Pinto, 1994, p. 240).

Podemos encontrar, ainda, outras informações sobre esses cursos, com detalhes que ilustram parte dos argumentos desenvolvidos no presente artigo. Por exemplo, o jornal O Progresso publica, em 1929, o fechamento de uma escola, na cidade de São Paulo, que funcionou durante dez anos, atendendo afrodescendentes de ambos os sexos. O fechamento se deu por falta de subvenção, ou seja, era mantida exclusivamente pelos membros da Sociedade Beneficente Amigos da Pátria, fundada em 13 de maio de 1908 (O Progresso, 26/09/1929, p. 2 e 7).

Como se pode ver, o Progresso teve um importante papel no registro das atividades educacionais e culturais promovidas pelas associações negras. Da mesma forma que publicava o fechamento de uma escola, divulgava a atividade de outras entidades com o intuito de colocar à disposição da comunidade negra serviços educacionais que poderiam lhe ser úteis. Em 1930, o jornal registrava a existência de uma escola, na cidade de São Paulo, mantida pelo clube 13 de Maio dos Homens Pretos. Esta escola oferecia cursos para os filhos dos associados bem como cuidava da "alfabetização daqueles que trabalham durante o dia" (O Progresso, 28/09/1930, p. 4).

A alfabetização dos adultos era preocupação constante. Já em 1924, o periódico Getulino divulgava longo artigo do estudioso negro, prof. Norberto de Souza Pinto, que discorria sobre "a desanalfabetização", destacando a conveniência de políticas públicas e tentando convencer seus leitores da importância do domínio das letras (Getulino, 1924, p. 4).

Este trabalho de convencimento adentra a década de 30. Em 1936, o jornal $O$ Alvorada apresenta matéria veemente quanto à necessidade de crianças e adultos saberem ler, escrever, contar. Ensina como proceder para se matricular em cursos. Dá conselhos no sentido de que se abra mão de horas de lazer ou de descanso do trabalho, para “adquirir tão valioso instrumento" (Alvorada, 1936, p. 2).
Esses exemplos nos mostram que a escolarização promovida pelas associações negras não se dissociava dos serviços de assistência social. Estas duas modalidades caminhavam juntas, e nem sempre era possível discernir a qual delas se dava prioridade (Gonçalves, 2000).

A imprensa negra refletia, de certa forma, uma importante dimensão da educação dos negros, a saber: educação e cultura apareciam quase como sinônimos na maioria dos artigos publicados pelos jornais militantes da época. Não só divulgavam cursos como também apresentavam a agenda cultural das entidades. Nesta agenda, incluíam-se atividades do tipo: biblioteca, conferências, representações teatrais, concertos musicais e outros.

Em algumas entidades como, por exemplo, o Grêmio Kosmos, mantinha-se uma biblioteca ativíssima, que organizava, entre outras atividades, grupos de teatro amador e promovia conferências para seus membros. Alguns autores têm insistido no papel dessas conferências na formação da opinião pública no meio negro. Teriam elas sido importante aliado na difusão de idéias do combate ao racismo, uma vez que poderiam atingir um público não alfabetizado, ou seja, um público que teria dificuldade de aceder às informações da imprensa escrita (Gonçalves, 2000).

Fazia-se, assim, um esforço contínuo para convencer os que acreditavam que "estudo não era para negro, para pobre", que a estes somente restaria o trabalho duro. Por isso, além dos jornais a que tinham acesso principalmente os alfabetizados, destacado papel tinham os oradores que se manifestavam em frente aos grandes jornais em ocasião de reivindicações, diante dos túmulos dos abolicionistas por ocasião do 13 de maio e também nas festas. Como nos lembra o ex-militante dos anos 20, Antunes Cunha, "os bailes eram interrompidos para que um orador trouxesse mensagem forte, fosse a respeito da data comemorativa como 7 de setembro, quando se aproveitava para exortar os negros a educar-se, a lutar por seus direitos; fosse para mostrar o valor do negro na construção da sociedade brasileira" (Cunha, 1991).

Até o momento, podemos dizer que a leitura desses registros nos levam a sustentar a hipótese de que o abandono a que foi relegada a população negra motivou os movimentos negros, do início do século, a chamar para 
si a tarefa de educar e escolarizar as suas crianças, os seus jovens e, de um modo geral, os adultos.

Não há quase referência quanto à educação como um dever do Estado e direito das famílias. As entidades invertem a questão. A educação aparece como uma obrigação da família. A crítica ao descaso do governo para com a educação dos negros aparece na mesma proporção em que o protesto racial endurece, ou seja, se radicaliza. Dentre os jornais que compõem a imprensa negra paulista no período em questão, $A$ Voz da Raça, Jornal da Frente Negra Brasileira, ilustra muito bem o que acabamos de dizer.

Em 1934, Raul Joviano do Amaral denuncia, em um artigo intitulado "Burrice", a falta de apoio material, por parte do governo, dificultando o trabalho educativo das entidades. Raul refere-se à campanha próinstrução, encabeçada pela Frente Negra Brasileira, que se expandiu para os estados de Minas Gerais, Bahia e Rio Grande do Sul. Apesar de registrar os benefícios que tal campanha estava propiciando à "gente de cor", ele mostrava que essas entidades estavam se ressentindo "de falta de apoio material", pois as aulas eram "ministradas em salinhas acanhadas, com bancos toscos e mesas de caixão". E assim mesmo, tudo isto era "custeado por bolsa de particulares" (Raul J. do Amaral, Burrice, A Voz da Raça, 23/06/1934, p. 1).

Outra crítica veemente é lançada aos estabelecimentos de ensino oficiais. O militante Olímpio Moreira da Silva, em artigo publicado em 1934, nos diz: "Ainda há grupos escolares que recebem negros porque é obrigatório, porém os professores menosprezam a dignidade da criança negra, deixando-os de lado para que não aprendam, e os pais pobres e desacorçoados pelo pouco desenvolvimento dos filhos resolvem tirá-los da escola e entregar-lhes serviços pesados" (A Voz da Raça, 17/ 02/1934).

Havia, da parte da imprensa, um movimento de incentivo à educação. Mas tinha-se a consciência de que, com a educação fornecida pelos estabelecimentos de ensino, os estudantes negros não deveriam afastar-se da educação de tradição africana, tampouco deixar-se aprisionar por ideologias que pretensamente os levassem à aceitação pelas classes poderosas da sociedade e, assim, afastar-se de seu grupo racial. Aos pais chamava- se-lhes a atenção em termos como os do militante Alcides Costa: "o que lhes importa fazer imediatamente, é incutir em seus filhos o respeito aos antepassados, a convicção de que são livres no corpo e no espírito, o desejo em fazer algo em prol da cor" (O Clarim d'Alvorada, 1930, p. 4).

Com a finalidade de enfatizar o valor da educação e de elevar a auto-estima dos leitores, os jornais publicavam na data de nascimento ou morte de proeminentes intelectuais negros suas bibliografias e palavras em que se destacavam a necessidade e o valor da educação. Entre outros estavam Cruz e Souza, André Rebouças, José do Patrocínio e notadamente Luiz Gama, cuja carta ao filho foi reiteradas vezes divulgada, destacando-se a seguinte passagem: "crê que o estudo é melhor entendimento e o livro o melhor amigo. Faze-te apóstolo dele desde já" (O Clarim d'Alvorada, 1935).

Publicaram-se artigos que combatiam o suposto lugar de inferioridade das mulheres negras no mundo do trabalho. Já era uma tentativa de romper com a seqüência: escrava, empregada doméstica. Menções à educação para mulheres se fazem nos anos 30, destacadamente em propagandas de cursos para aprender a costurar e datilografar. Uma das propagandas divulgada pelo Clarim d'Alvorada, referente a um curso de datilografia, dizia: "na vida ativa de nossos dias, mobilizando todos os seres capazes, não podia deixar (de fora) como elemento de primeiro plano, a mulher [...], principalmente aquela [que] pela instrução se tornou capaz para certos serviços como o homem". Buscava-se convencer os pais das vantagens de uma educação moderna e, só por si, capaz de libertar suas filhas de uma situação de manifesta inferioridade moral e material (idem, p. 5).

A tradução de breves artigos de negros de países africanos e das Américas, com certa freqüência de estadunidenses, tinha o objetivo de incentivar os negros brasileiros a freqüentarem cursos, a se educarem. $\mathrm{O}$ Clarim d'Alvorada publica, em 07/04/1929, o manifesto "Negro World", divulgado em Nova Iorque e traduzido com o título "Eduquemos nossas Massas" (p. 2). Divulga também um artigo do escritor africano Abantu Batho sobre educação para a liberdade de negros e brancos (p. 2). Traz ainda informações acerca de heróis negros da Abolição da escravatura em outros países, como 
Toussain l'Ouverture, do Haiti, além do pensamento de líderes e intelectuais como Marcus Garvey e DuBois.

A experiência escolar mais completa do período em consideração foi empreendida pela Frente Negra Brasileira. Raul Joviano do Amaral, na época presidente desta entidade, elaborou uma proposta ousada de educação política com os seguintes objetivos: agrupar, educar e orientar (Gonçalves, 2000). Criou uma escola que só no curso de alfabetização atendeu cerca de 4.000 alunos. E a escola primária e o curso de formação social atenderam 200 alunos. A maioria era de alunos negros, mas aceitavam-se também alunos de outras raças. $\mathrm{O}$ curso primário foi ministrado por professores formados e regularmente remunerados. Outros cursos foram assumidos por leigos e não remunerados (Pinto, 1994, p. 242).

Os líderes viam a educação como algo que deveria ser realizado pela própria iniciativa dos negros. Havia um projeto na Frente Negra Brasileira de criação do "Liceu Palmares" com o objetivo de ministrar ensino primário, secundário, comercial e ginasial aos alunossócios. Mas aceitaria também não-sócios e brancos, brasileiros ou não (A Voz da Raça, 25/03/1933, p. 4). O mais surpreendente é que o Liceu deveria funcionar em todo o Estado de São Paulo. Segundo os entrevistados de Regina Pahim Pinto, os idealizadores deste Liceu eram negros que haviam estudado em escolas da elite paulistana, como, por exemplo, Colégio São Bento, Coração de Jesus, e que, por isso, se julgavam capazes de criar uma organização escolar frentenegrina nos mesmos moldes daquelas duas instituições. O projeto fracassou: faltaram recursos (Pinto, 1994, p. 243).

$\mathrm{Na}$ Frente Negra Brasileira, a educação dos afrodescendentes de ambos os sexos não se reduzia exclusivamente à escolarização, embora este tenha sido o leitmotiv da reforma educacional proposta pelos líderes frentenegrinos. Pesa de forma exemplar a idéia de que, para efetuar uma mudança significativa no comportamento das negras e dos negros brasileiros, seria necessário promover junto à escolarização, um curso de formação política. Séculos de escravidão haviam deformado a própria imagem dos negros, afetado profundamente sua auto-imagem. Entendiam os líderes que a flagrante apatia que assolava a massa de população negra, a entrega desenfreada a vícios urbanos, a ausência de dispo- sitivos psicossociais que ajudassem a integração dos negros na ordem competitiva, tudo isto era resultado de um passado escravista que ainda perdurava na alma do homem livre negro, abandonado à própria sorte nas periferias das cidades brasileiras (Fernandes, 1986; Gonçalves, 1997).

A educação política já existia enquanto projeto, quando da criação do Centro Cívico Palmares, em 1926. Este funcionava como uma escola de formação de lideranças. A quase totalidade dos membros das diretorias da Frente Negra Brasileira foi integralmente formada naquele Centro. Mas, ao reproduzirem a experiência de educação política nas escolas frentenegrinas (lembrando que estas foram expandidas a outros Estados), há um certo amadurecimento no que se refere aos objetivos de luta.

Regina Pahim Pinto chegou muito perto do que poderia ter sido o curso de formação política frentenegrina. Na realidade, era chamado de curso de formação social, e seu currículo baseava-se em aulas de história, educação moral e cívica e conhecimentos gerais. Tinha a mesma estrutura de um curso ginasial, embora sem reconhecimento oficial (Pinto, 1994, p. 241). Entretanto, a autora não confirma a sistematicidade do referido curso. Segundo seus informantes, eram conferências, proferidas em espaços de tempo não regulares. Introduziase, já, uma história do negro brasileiro para combater a história oficial (idem, p. 247). Em suma, era uma formação voltada sobretudo para aqueles que freqüentavam o curso de alfabetização de adultos.

Essa experiência de escolarização, mesmo tendo sido interrompida com o fechamento da Frente Negra pela ditadura de Vargas, iniciou um novo debate sobre a educação dos negros no Brasil, cujos ecos serão ouvidos nos anos subseqüentes.

Os poucos dados que reunimos acima mostram que, naquele momento, a escolarização e a educação profissional eram, para os negros, necessárias e obrigatórias. A questão é saber por que os movimentos negros chamam para si a responsabilidade de educar? Por que não viam a educação como um dever do Estado?

Para responder mais adequadamente essas duas questões, seria necessário agrupar mais informações acerca do que se passava em outros estados da federa- 
ção. Por exemplo, como os militantes negros do Rio Grande do Sul, da Bahia e de Minas Gerais estavam enfrentando as questões educacionais. Como já relatado anteriormente, cada qual em seu contexto estava igualmente abandonado à própria iniciativa. Em Minas Gerais, o militante Antonio Carlos desenvolve, como os paulistas, a mesma experiência de uma escolarização mantida pelas próprias entidades negras. Começa sua luta, em Barbacena e, no início dos anos 50, dirige a entidade José do Patrocínio, em Belo Horizonte, cujos fins eram educacionais (Gonçalves, 2000).

No Rio Grande do Sul, vale consultar os registros apresentados por Eliane Teresinha Peres (1995) sobre o papel de líderes negros na cidade de Pelotas no início do século XX. Apenas lembrando, esses líderes foram alunos de um dos "cursos noturnos masculinos de instrução primária" oferecidos pela biblioteca pública pelotense. O referido curso funcionou no período entre 1875 e 1915. Segundo a autora, esses alunos negros estiveram à frente de entidades operárias ou dos movimentos negros. Dois deles fundaram, em 1907, o jornal O Alvorada. Segundo os relatos, o referido jornal lutou pela emancipação dos afrodescendentes, "na defesa da instrução, da unidade racial e do progresso e interesses da terra pelotense" (Peres, 1995, p. 147-148). Um dos proprietários do jornal, Durval Moreno Penny, era médico e militante, tendo lutado, como nos diz Peres, "pela causa dos negros, não apenas através do jornal”, mas também como diretor do "Instituto São Benedito", educandário dedicado à educação de meninas negras (idem).

Quanto mais informações reunimos, mais nos convencemos de que, respeitadas as diferenças regionais e até mesmo locais, a forma como os negros militantes buscaram reagir à precária situação educacional de seu grupo étnico exigiu deles um tipo de compromisso pessoal, de engajamento direto para resolver um problema que não era exclusivamente dos negros, mas era um problema nacional.

Para Fernandes, o clima político do início do século, impregnado de ideologia liberal, moldava os indivíduos, ao ponto de imaginarem que a tão almejada integração social, acompanhada de um obsessivo desejo de mobilidade social, dependia exclusivamente do esforço de cada um. Ou seja, havia um cenário cujo ethos cultu- ral desenhava uma "sociedade aberta", repleta de oportunidades das quais todos poderiam desfrutar com chances iguais (Fernandes, 1986). Isto talvez explique os conflitos no próprio interior do meio negro. Militantes mais arrojados acabavam afastando possíveis adeptos da causa negra, simplesmente porque viam neles apatias, falta de vontade, promiscuidade ou até uma mentalidade de escravo que ainda não havia se libertado do cativeiro (Gonçalves, 1997).

Essa autonomia tão idealizada, reforçando e valorizando iniciativas que partissem do próprio negro, poderia ter sido também moldada na convivência com o imigrante europeu. Fernandes sugere que muito do comportamento desenvolvido pelos negros paulistas fora resultado de um processo de imitação. Alguns militantes negros da época corroboram a referida hipótese. Correia Leite, em seu livro de memórias, diz isto. Segundo ele, "se os italianos podem promover-se, contando apenas com seus próprios esforços, sem precisar de favores do Estado, porque nós negros não podemos nos promover apoiados em nossos próprios recursos" (Cuti \& Correia Leite, 1992).

A hipótese da imitação é plausível, só não é generalizável, porque a referida convivência entre negros e imigrantes não ocorreu em todo o país com a mesma intensidade com que ocorreu em São Paulo, e mesmo nos estados do Sul.

A posição de algumas entidades negras no Nordeste não deixa dúvida de que, ali também, os negros tiveram que, inicialmente, assumir para si os encargos da educação de seu grupo étnico.

Foi criada em Recife, em 1936, a Frente Negra Pernambucana, que contava em seus quadros com o poeta negro Solano Trindade. Segundo José Vicente, um dos fundadores, "Solano era alma do movimento negro, sobretudo, aqui, no Estado de Pernambuco" (Vicente, 1988). Visando a educar as novas gerações e a promover a raça negra, o poeta do movimento teve de criar uma estrutura própria para este fim, que ficou conhecida como sendo o Teatro Popular Brasileiro (Cuti \& Correia Leite, 1992, p. 157). Reunia jovens negros e proletários, e, com eles, pesquisava em profundidade a manifestação da cultura afro-brasileira e organizava apresentações do grupo em todo país.

Talvez tenhamos de lidar com duas outras hipóteses. 
A primeira refere-se ao fato de que a passagem da Monarquia para República conservou antigas oligarquias nos governos republicanos. Para os negros, não havia qualquer motivo para crer nos donos do poder. Por que se encarregariam eles da educação dos negros? Haveria motivos para os negros desconfiarem dos propósitos republicanos?

Para alguns estudiosos do período em questão, sim, haveria muitos motivos. Como já dissemos anteriormente, Chalhoub examinou magistralmente as razões pelas quais os negros cariocas foram bastante hostis a algumas medidas da administração republicana (Chalhoub, 1988). Mas os militantes da época expressaram de diferentes maneiras o descontentamento com relação aos governos da República.

Veja-se, por exemplo, como O Clarim d'Alvorada manifestava sua posição de protesto contra o regime em vigor, ao convocar a mocidade negra para participar de um Congresso, que teria como objetivo discutir questões da raça e propor estratégias de promoção social. Diz o jornal: "Em quarenta anos de liberdade, além do grande desamparo que foi dado aos nossos maiores, temos de revelar com paciência, a negação de certos direitos que nos assistem, como legítimos filhos da grande pátria do cruzeiro. Se os conspícuos patriotas desta República não cuidaram da educação do negro, nosso congresso tratará desse máximo problema que está latente na questão nacional" (Clarim d'Alvorada, 07/04/1929, p. 1).

Parece-nos que o texto acima esclarece de onde nasce a convicção de fazer algo pela educação dos negros sem esperar muito do poder estatal.

Mas, adiante, ele esclarece alguns motivos que levavam os líderes negros a desconfiar dos "bons" propósitos dos republicanos no poder. Dizia, ainda, o texto: "notamos que os regeneradores da República são os primeiros a desmoralizarem a obra grandiosa e cívica do negro afetivo e obediente. Enquanto o negro fica parado na estrada do progresso, com seu título de eleitor, embrutecido quase pelos inúmeros vícios, sem olhar sua situação cada vez mais miserável, o estrangeiro avança usurpando os direitos que nos assistem [...] antes de se nomear um negro brasileiro para uma repartição pública, vê-se primeiro se os estrangeiros já estão colocados [...] estrangeiros indesejáveis sim, negros não" ( $O$ Clarim d'Alvorada, idem).
Ora, não há como desconsiderar, no texto, o sentimento de humilhação induzindo a uma baixa auto-estima. Para o grupo em situação de desvantagem, o fato de suas próprias iniciativas darem certo é motivo de regozijo. Um exemplo desta atitude pode ser visto em um artigo intitulado "Instrução", publicado em $A$ Voz da Raça, em 1933, que, ao falar dos projetos educacionais conduzidos pela Frente Negra e pelo Clube Negro de Cultura, ressalta que "o programa de instrução no meio negro ganha terreno dia a dia, crescendo sempre a olhos vistos [...], embora não conte com a produção oficial ela aí está patente aos olhos de todos" (A Voz da Raça, 08/ 07/1933, p. 2)

Os dados até agora examinados nos ajudam a recolocar a questão racial em outro patamar. Como se pode ver, contrariamente ao que se supunha, a ação dos movimentos negros se constituía muito mais na autonomia do que na tutela. Pouco se esperava do Estado, porque se desconfiava dele. Entre os militantes, esta atitude dura até o final dos anos 20. Pelos depoimentos de exmilitantes, a candidatura Vargas incendeia o debate no meio negro. Começam a vislumbrar a possibilidade de não ficarem mais parados "na estrada do progresso, com o título de eleitor na mão, embrutecidos pelos vícios". Reacende-se a esperança, que foi bem retratada por Correia Leite em suas memórias, ao saber que, com Vargas, os negros teriam grandes chances de ver "aquelas famílias de escravagistas apeadas do Poder" (Cuti \& Correia Leite, 1992, p. 91).

Encaminhamo-nos, assim, para a outra fase da luta pela educação no meio negro. Muitos de seus determinantes já estavam sendo construídos ao longo de todo o período até agora examinado, ou seja, não significa que a nova fase seja mais importante ou mais evoluída do que a anterior; mas que ela conta com condições diferentes daquelas que predominavam quando se tinha um conjunto de estados federativos no interior de uma unidade nacional frágil.

Quanto mais nos aproximamos da metade do século XX, mais podemos perceber um movimento negro com características mais nacionais do que regionais. Tudo isto ocorre no mesmo momento em que vai se efetuando a consolidação do próprio Estado nacional.

$\mathrm{O}$ fato de a centralidade do movimento negro ser 
mais percebida na cidade do Rio de Janeiro, neste momento, fins dos anos 40 e início dos 50, não é um acaso. $\mathrm{Na}$ Capital Federal, mobilizam-se forças de diferentes naturezas para interferir na Constituinte de 1946. Havia um enorme movimento em prol da democratização do país. Estudos de diferentes matizes já mostraram o quanto esse período foi fecundo em termos de aprendizado político. Muito se explorou no que se refere às alianças políticas. A existência de políticas públicas de caráter nacional, seja no campo do trabalho, da previdência ou mesmo da educação, exigia dos atores sociais uma visão de totalidade da realidade nacional.

Comparada às duas décadas precedentes, a de 50 representou, para o negro, um passo decisivo no sentido de estabelecer alianças com outros setores progressistas da sociedade. Embora nem sempre o resultado dessas alianças tenha dado um final feliz, o certo é que se buscou romper com um certo isolamento da militância negra.

Talvez uma das mais significativas alianças feitas pelo movimento negro seja a que estabeleceu com alguns setores da intelectualidade nacional ou estrangeira. Por exemplo, laços desse tipo já haviam ocorrido, com clareza, no Nordeste dos anos 30. De um deles resultou um importante movimento de valorização da cultura negra. Entre os aliados, estavam Jorge Amado e Edson Carneiro. Ambos criam, em 1930, com apoio de outros intelectuais baianos, a "Academia dos Rebeldes", em Salvador (Gonçalves, 1997). Esse movimento representou uma aliança interessante entre intelectuais e membros de cultos afro-brasileiros. ${ }^{4}$

Já no final dos anos 40 e início dos anos 50, essas alianças tiveram um tom acadêmico mais explícito. $\mathrm{O}$ encontro de intelectuais e militantes negros visava produzir conhecimento crítico acerca da situação dos afrodescendentes no Brasil. Foi neste movimento que pesquisadores como Guerreiro Ramos, Roger Bastide, Florestan Fernandes e outros se aproximaram das organizações negras e inauguraram, de certa forma, estudos que denunciavam o nosso paraíso racial.

\footnotetext{
${ }^{4}$ Maiores detalhes sobre esse movimento e seus personagens podem ser encontrados em Dantas (1984).
}

Desnecessário dizer que um dos indicadores da exclusão dos negros era a baixa escolarização da maioria da população negra. Não é por acaso que o movimento liderado por Abdias do Nascimento fará da educação uma das maiores bandeiras de luta em prol da raça negra (Nascimento, 1978).

À medida que avançamos no tempo, as exigências das novas gerações, no meio negro, aumentam. Não se reivindicava apenas acesso ao ensino fundamental, queria-se mais: ensino médio e universitário (Gonçalves, 1997).

A entrada de idéias revolucionárias no país incitava o debate e ampliava o horizonte da juventude negra brasileira. O tema da Negritude se tornou central para a imprensa negra nos anos 50. As idéias de Aimé Cesaire, Senghor, Léon Damas, Langston Hughes, ajudavam no combate aos preconceitos baseados na cor e na raça (Cuti \& Correia Leite, 1992, p. 167).

Foi, portanto, neste contexto que o movimento negro recolocou a questão da educação em sua agenda política.

No Rio de Janeiro, a organização que mobilizou o protesto racial, no período em consideração, foi o Teatro Experimental do Negro (TEN). Tal como a Frente Negra, ele se expandiu para outros estados e cidades do país.

Sob a liderança de Abdias do Nascimento, o TEN teve papel importante na Constituinte de 1946. Militantes viajavam pelo Brasil para preparar, com entidades e organizações negras de outros estados, o evento que ficou conhecido como Convenção Nacional do Negro Brasileiro - CNNB (Nascimento, 1981).

Foi no período da preparação da Convenção que o TEN ampliou suas alianças em nível nacional. Via-se, naquele evento, uma oportunidade de os militantes poderem discutir questões raciais, de diferentes partes do país, sem fragmentá-las ou considerá-las como simples conflitos localizados. A CNNB funcionava, assim, como uma entidade supra-regional visando à conquista efetiva da cidadania dos negros brasileiros (Gonçalves, 1997, p. 454). E tinha um caráter rigorosamente provisório (Nascimento, 1978).

Embora haja informações de apoios recebidos de militantes do Norte e Nordeste, ficou evidente que a Convenção foi, antes de mais nada, o resultado de negocia- 
ções entre as organizações negras paulistas e cariocas. Em 1945, a Associação dos Negros Brasileiros (ANB) lançou o Manifesto de Defesa à Democracia. Neste mesmo ano, militantes cariocas criam o Comitê Democrático Afro-Brasileiro. Conseguiram apoio inicial da União Nacional dos Estudantes (UNE). A Convenção se realizou, em São Paulo, com a participação de 500 militantes e representantes de organizações negras de todo o país (Nascimento, 1981, p. 192). No encontro foram elaboradas as proposições que os líderes negros gostariam de ver integradas no novo texto constitucional. A segunda reunião realizou-se no Rio de Janeiro, em 1946. Concluído o trabalho inicial, os militantes lançaram o Manifesto à Nação Brasileira no qual figuravam suas reivindicações como cidadãos (Nascimento, 1978).

Entretanto, não houve apoio parlamentar, sob a famosa alegação de que "as reivindicações restringiam o sentido mais amplo da democracia constitucional" (Nascimento, 1981, p. 190), e, ainda, segundo os ilustres congressistas, que "faltavam, no texto, exemplos concretos de discriminação racial no Brasil" (idem). Para completar, a UNE retirou seu apoio inicial, acusando o trabalho de defesa dos afro-brasileiros de racismo ao inverso (idem, p. 144).

Diante dessa situação, os movimentos negros retomam suas atividades de combate ao racismo. São mais uma vez remetidos à situação de que deveriam assumir, por si sós e por iniciativa própria, a defesa da raça negra.

O Projeto do TEN abria muito concretamente caminhos inéditos para pensar o futuro dos negros e o desenvolvimento da cultura brasileira (Gonçalves, 1997, p. 428-452). O objetivo central era combater o racismo. Para tanto, propunha questões muito práticas do tipo: instrumentos jurídicos que garantissem o direito dos negros, a democratização do sistema político, a abertura do mercado de trabalho, o acesso dos negros à educação e à cultura, e a elaboração de leis anti-racistas. ${ }^{5}$

${ }^{5}$ Diferentemente do período anterior, a fase do TEN está muito bem documentada. O projeto de que falamos acima foi publicado integralmente. Suas partes podem ser encontradas em todos os números do jornal Quilombo, sob o título: "Nosso Programa".
No que se refere ao acesso à educação, o TEN tinha proposições relativamente realizáveis: "ensino gratuito para todas as crianças brasileiras, admissão subvencionada de estudantes nas instituições de ensino secundários e universitário, de onde foram excluídos por causa de discriminação e da pobreza resultante de sua condição étnica" (Nascimento, 1978, p. 193).

Em termos concretos, o TEN acreditava que seria possível combater o racismo por meio de procedimentos culturais e educativos, restituindo a verdadeira imagem histórica do negro (idem).

As propostas que nascem no interior do movimento negro carioca resultavam de um diagnóstico profundo feito por um dos mais instigantes sociólogos brasileiros, Guerreiro Ramos. Conhecido por suas posições polêmicas e pelos embates que travou com expoentes das Ciências Sociais no Brasil, como Roger Bastide, Florestan Fernandes, Luiz Costa Pinto e Gilberto Freyre, o livre-pensador e militante negro Guerreiro Ramos interpretava a situação dos negros brasileiros por lentes pouco otimistas. Segundo ele, a situação de servidão fez com que os negros entrassem sem preparo no mundo dos homens livres. Pobres e analfabetos, estavam impedidos psicologicamente de desenvolver estímulos mentais mais apropriados à vida civil (Gonçalves, 1997, p. 123-124).

Em suma, o projeto político do TEN apontava para uma outra visão relativa ao que se chama direito à educação. Como se pode ver, ele fala a linguagem de sua época. Aqui, educação é indiscutivelmente dever do Estado. É direito dos cidadãos. Não por acaso, os idealizadores do Teatro Experimental do Negro criticam radicalmente o modelo proposto pelos militantes paulistas. Segundo eles, assumir para si aquilo que seria tarefa do Estado, acabou criando uma espécie de isolamento do negro, um tipo de gueto (Gonçalves, idem, p. 125-126). A esse respeito, Guerreiro Ramos não poupava palavras. Via o otimismo dos frentenegrinos como uma espécie de afecção mórbida, resultante de uma incapacidade de agir (Guerreiro Ramos, 1966, p. 84).

Guerreiro Ramos se recusava veementemente a aceitar a idéia de que havia um problema do negro. Para ele, era o branco que pensava o negro como um problema. Nesta perspectiva, via que a situação de precarie- 
dade em que vivia a população negra, aí incluída a baixa escolarização, não era um problema do negro, mas um problema nacional.

Vale a pena comentar, em bloco, as idéias principais do movimento negro dos anos 40 e 50, um vez que elas vão, a nosso ver, se fazer presentes em propostas mais recentes.

Reivindicavam ensino fundamental gratuito para todas as crianças (brancas e negras), ou seja, o projeto educacional visava a sociedade como um todo. O que não ocorre quando se refere ao ensino secundário e universitário. Neste caso, há a defesa de seu grupo étnico. Fala-se em subsídios para os negros, uma vez que, nesses dois níveis de ensino, a democratização está longe de ser realizada. São muito seletivos e baseiam sua seleção em critérios de classe e de raça (Hasenbalg, 1979, Barcelos, 1992).

Há, entretanto, algo novo no projeto do TEN: educação e cultura se entrelaçam. Entendem seus idealizadores que a escolarização, pura e simples, não bastaria para criar aquilo que Guerreiro Ramos chamou de "estímulos mentais apropriados à vida civil”. Segundo ele, os negros desenvolveram um profundo sentimento de inferioridade cujas raízes estão na cultura brasileira. Para libertá-los desse sentimento não basta simplesmente escolarizá-los; seria preciso produzir uma radical revisão dos mapas culturais, que as elites e, por conseqüência, os currículos escolares, elaboraram sobre o povo brasileiro. Aliás este foi o tema do I Congresso do Negro Brasileiro (Quilombo, $\mathrm{n}^{\text {os }} 5$ e 6 ). ${ }^{6}$

Naquele momento, o TEN pensou em duas estratégias que poderiam apontar a solução para o estado patológico nacional. A primeira foi a de tratar a experiência dramática no teatro como uma espécie de psicoterapia de grupo, na qual os recalques, as neuroses, os sentimentos mórbidos, seriam representados cenicamente. Por meio dessas experiências, os negros poderiam se libertar psicologicamente e os brancos poderiam se livrar de suas atitudes racistas. Já a segunda estratégia previa a

${ }^{6}$ Elisa Larkim do Nascimento (1981) faz um estudo interessante sobre os conflitos no interior desse Congresso. Cf. principalmente o capítulo intitulado: I Congresso: sabotagem acadêmica e resistência negra (p. 198-205). formação de autores capazes de remapearem e criticarem em profundidade as raízes eurocêntricas da cultura brasileira (Gonçalves, 1997, p. 441).

A relação entre cultura e educação, inaugurada nas práticas e propostas do movimento de protesto do Teatro Experimental do Negro, será retomada em outros momentos em que o Movimento Negro Brasileiro busca interferir nas políticas educacionais do país.

Para finalizar o presente artigo, examinaremos, de forma pontual, como, a partir dos anos 80, principalmente após a criação do Movimento Negro Unificado, em 1978, as questões educacionais referentes à população negra brasileira passam a ser tratadas nos debates públicos em geral.

Desde seu manifesto primeiro até os desdobramentos que sofreu ao longo de 20 anos, com a proliferação de inúmeras entidades negras em todo país, o Movimento Negro pós-78 tem colocado a educação como prioridade de sua luta.

Seria praticamente impossível fazer uma síntese das múltiplas iniciativas organizadas na área educacional, no período supracitado. Primeiro porque não dispomos nem de fontes, nem de registros suficientes que possam nos dar minimamente um retrato grosseiro dessas ações. Segundo, porque essas ações são de naturezas muito diferentes, por vezes, incomunicáveis entre si. Terceiro, porque as próprias entidades que empreendem ações no campo educacional, seja por conta própria, seja em consonância com os sistemas de ensino, muitas vezes não registram suas experiências. E quarto, porque há poucos estudos históricos tratando das questões educacionais referentes à população negra brasileira no século $\mathrm{XX}$. Isto tem gerado uma lacuna enorme no conhecimento sobre esse assunto.

Comecemos, assim, registrando aqueles que, de certa forma, introduzem novas questões para compreender como as entidades negras pós-78 buscaram interferir na situação de abandono e de exclusão dos negros em relação ao sistema educacional.

Inicialmente, o próprio movimento negro gerou novas organizações, mais competentes para lidar com o tema da educação. Isto se explica, em parte, pelo aumento do número de militantes com qualificação em nível superior e médio. Passa-se a compreender melhor os 
mecanismos da exclusão e, por consequiência, como combatê-los de forma mais eficiente.

A via acadêmica, por maior que seja a crítica que a ela se possa fazer, aumentou a comunicação entre os pesquisadores que estudam o assunto, e entre estes e os militantes negros. Pelos registros que tínhamos disponíveis, parece-nos que esse aumento de comunicação propiciou novas formas de trocas de experiências, e, mais do que isso, de conhecimento.

Não é possível, por ora, fazer um balanço da produção acadêmica sobre o tema das relações raciais e educação. Em estudo anterior, mostramos que, nos programas de pós-graduação em educação, a produção sobre o tema foi muito pequena, em 15 anos não ultrapassou a marca de 20 trabalhos: 1 tese e 19 dissertações (Gonçalves \& Silva, 1998, p. 102).

Entretanto, devemos ressaltar que o grosso da produção tem sido realizado fora da academia. Esses trabalhos têm sido feitos por estudiosos e militantes, muitos dos quais vinculados a entidades negras. Mais adiante mostraremos alguns exemplos dessas produções em Florianópolis. Mostraremos também que, embora a educação tenha se universalizado, por meio da escola pública e gratuita, ela continua sendo um dos campos de ação das organizações negras. Hoje esses campos têm sido assumidos por organizações não-governamentais.

As informações acima citadas foram recolhidas em Encontros e seminários. Isto significa dizer que, por ora, elas estão dispersas e fragmentadas, não permitindo um estudo mais sistemático das produções sobre o tema das relações raciais e educação, fora do mundo acadêmico.

Talvez valesse a pena apresentar alguns desses encontros, explicitando sua natureza. Alguns deles tinham um cunho político, no sentido de discutir estratégias de combate ao racismo na escola, articulando forças sociais, fossem elas ligadas a partidos políticos, a setores da igreja, a sindicatos e a movimentos sociais. Mas outros, embora conservassem um conteúdo político, não tinham por objetivo definir estratégias de combate, mas apresentar resultados de pesquisas. Parece-nos importante fazer este tipo de distinção, porque, no campo do qual estamos falando, pesquisa e militância por vezes se misturam, ao ponto de se obscurecerem. Como um dos objetivos do presente artigo é esclarecer como os movimentos negros lidavam com a situação do abandono e da exclusão educacional, manteremos esta distinção.

Comecemos, então, pelo documento que, a nosso ver, funda uma nova perspectiva de luta contra o racismo no Brasil, que é o próprio Manifesto Nacional do Movimento Negro Unificado Contra a Discriminação Racial, apresentado em 4 de novembro de 1978. Nele, ao mesmo tempo em que os militantes declaram à nação que estão em luta contra o racismo, eles instauram o dia da Consciência Negra, ${ }^{7}$ repassam séculos da história dos negros no Brasil e, ainda, propõem combater o racismo onde o negro estiver. Em suma trata-se de um "testamento deixado aos herdeiros de Zumbi. É, sem dúvida alguma, um documento histórico e sociológico de enorme importância. Articula, de forma surpreendente, o passado e o presente" (Gonçalves, 1997, p. 477).

Como um dos lugares onde negro vive é a escola, ou seja, os sistemas de ensino, buscou-se orientar a ação de combate ao preconceito nesses ambientes. Entre 1978 e 1988, muitos encontros ocorreram com esse objetivo.

Entretanto, o primeiro encontro, após 78, de que temos registro, no qual os problemas referentes à raça e educação tiveram um espaço de debate, foi um evento de caráter nacional, que reunia pesquisadores e professores de pós-graduação em educação. Foi a Conferência Brasileira de Educação, CBE, de 1982, realizada em Belo Horizonte. Organizou-se uma mesa redonda cujo tema era a discriminação nos sistemas de ensino. ${ }^{8}$

Tendo em vista a importância acadêmica do referido evento, vale aqui tecer alguns comentários quanto à iniciativa de agregar o tema do preconceito racial na escola como uma possibilidade de este vir a ser um objeto de investigação científica nos Programas de Pós-

${ }^{7}$ A evocação do primeiro 20 de novembro como dia da Consciência Negra ocorreu em 1971 como promoção do professor e poeta Oliveira Silveira no grupo Palmares, em Porto Alegre (RS).

${ }^{8}$ Conferir os anais da CBE de 1982. Na ocasião, foram apresentados dois trabalhos: Luiz, Maria do Carmo et al. A criança negra e a Educação; e Gonçalves, Luiz Alberto Oliveira. Discriminação racial em Escolas Públicas de Minas Gerais. 
Graduação. Parece-nos que a abertura para discussão da temática racial na CBE coaduna-se muito com o clima ideológico da época. Estávamos em processo de redemocratização. Movimentos sociais de diferentes naturezas apontavam para novos objetos de estudos. Cremos que não seja um acaso, também, o fato de que, a partir do referido período, aumentou-se significativamente a produção teórica (dissertações e teses) tratando de questões das mulheres na educação; começam aparecer estudos que investigam necessidades educacionais de grupos excluídos ou minoritários (Silva e Gonçalves, 1998, p. 103-105).

Outro dado importante refere-se à Convenção do Movimento Negro Unificado, realizada também em Belo Horizonte, em 1982, momento em que as delegações aprovaram o Programa de Ação do M.N.U. Entre as estratégias de luta, propunha-se uma mudança radical nos currículos, visando a eliminação de preconceitos e estereótipos em relação aos negros e à cultura afro-brasileira na formação de professores com o intuito de comprometê-los no combate ao racismo na sala de aula. Enfatiza-se a necessidade de aumentar o acesso dos negros em todos os níveis educacionais e de criar, sob a forma de bolsas, condições de permanência das crianças e dos jovens negros no sistema de ensino (Programa de Ação, 1982, p. 4-5).

Não podemos esquecer que, ainda em 1982, houve mudanças significativas nos governos estaduais e nas capitais do país. Em algumas administrações desses estados, foram organizados grupos de assessoria para assuntos da comunidade negra. Neste período, secretarias de educação e secretarias de cultura passaram a contar com assessores que, entre outras coisas, buscavam interferir nos currículos escolares, nos livros didáticos e assim por diante. Foram os casos das Secretarias do Estado da Educação de São Paulo e da Bahia, e da Secretaria de Cultura do Município do Rio de Janeiro. Nas administrações subseqüentes, essas assessorias foram criadas em outros estados da Federação, como Mato Grosso do Sul, Minas Gerais, Distrito Federal e outros.

Como praticamente em todos os casos supracitados, os assessores eram recrutados na própria comunidade negra, não surpreende que muitos vinham da militância em movimentos, em partidos ou sindicatos, e que, de certa forma, tinham algum vínculo com a academia. Esta dupla inserção gerou um tipo de comunicação entre essas instâncias, que nos permite inferir aspectos pontuais da questão. Por exemplo, aumenta-se o interesse pelo estudo das relações inter-raciais na escola. Entretanto, este interesse não correspondeu a um aumento de estudos na área. Os poucos que começam a pesquisar o tema são na maioria os próprios negros (Gonçalves, 1999).

Em todo caso, a presença desses assessores junto às administrações públicas acaba organizando as prioridades em termos de pesquisa, ou seja, apontam quais seriam os temas mais relevantes.

Dentro ainda da dispersão de documentos examinados pudemos encontrar alguns que relatam experiências educativas envolvendo a educação da população negra, que podem ou não passar pela escola.

As chamadas experiências comunitárias ou educação comunitária foram largamente utilizadas no período em consideração. Seria impossível querer fazer um balanço completo dessas práticas pedagógicas, até porque, na sua maioria, não sofreram nenhum tipo de registro.

Entre 1983 e 1984, o Instituto de Recursos Humanos João Pinheiro, na época vinculado à Fundação de Assistência ao Estudante do Ministério da Educação, realizou, em sua sede em Belo Horizonte, uma série de eventos que tinha por objetivo produzir algum registro de experiências de educação comunitária no país. No material coletado encontravam-se várias referências a práticas educativas que visam à educação de comunidades negras. Uma das experiências estava sendo realizada em Poços de Caldas, Estado de Minas Gerais. Mas a maioria, na época, concentrava-se na cidade do Rio de Janeiro e em Salvador.

No caso do Rio, eram experiências em geral vinculadas às escolas de samba, consideradas como importantes pólos de organização negra comunitária. Tivemos oportunidade de, posteriormente, conhecer o trabalho de assessores para assunto de comunidade negra, que atuavam na Secretaria da Cultura do Município do Rio de Janeiro e que, de uma certa forma, relataram como as crianças, os jovens e a comunidade em geral vinham se beneficiando dos projetos de educação comunitária ( $\mathrm{Ca}$ dernos de Pesquisa, 1987). 
Já em Salvador, havia mais registros dessas experiências. O pesquisador e educador Marco Aurélio da Luz apresentou, no II Encontro de Educação Comunitária, organizado pelos Instituto de Recursos Humanos João Pinheiro, os resultados de um projeto muito interessante que havia sido desenvolvido por uma comunidade de Candomblé, na Bahia. Criaram uma escola no interior do terreiro para atender crianças e jovens da redondeza. Estes tinham todos os clássicos conteúdos escolares, mas desenvolviam, ao mesmo tempo, elementos da cultura nagô. Da avaliação do relator, depreendiase que os alunos, à medida que não precisavam, ao entrar na escola, descartar os valores da cultura de seus ancestrais, sentiam-se mais integrados na comunidade e demonstravam uma visível melhora em seus rendimentos (Cadernos de Educação Comunitária, 1983).

Mas as experiências de educação comunitária em Salvador extrapolavam os limites da pura escolarização. Em um texto comemorativo do Movimento Negro Unificado, Jonatas C. da Silva apresenta algumas experiências educativas na Bahia, ligadas aos blocos afros e aos afoxés, que haviam tido grande influência na preparação da comunidade negra para lutar nos seus direitos e combater o racismo (Silva, 1988).

Existem outras experiências que vão na mesma direção, mas acrescentam pouco ao que já foi dito anteriormente. Passemos, assim, para outras situações em que podemos observar como uma entidade negra pôde envolver professores da rede pública de ensino, sem precisar recorrer aos mecanismos da administração pública.

Temos, também, neste caso, vários exemplos que se multiplicaram por todo o país. Mas o objetivo aqui não é fazer uma estatística desses eventos e, sim, mostrar como eles têm cumprido um papel importante na história da educação dos negros brasileiros.

Tomemos, como exemplo, os eventos organizados por uma das mais tradicionais e insuspeitas organizações negras no Brasil, a Sociedade Beneficente e Cultural Floresta Aurora, de Porto Alegre. Entidade fundada em 1872, conserva em seu patrimônio uma importante história de luta contra o racismo no Brasil. Entre suas iniciativas visando à educação, ainda no século passado, conforme registros em livros e atas da entidade, como lembra o militante Nelson Santana, está a reserva finan- ceira formada com a contribuição que os associados retiravam de seus salários para que fosse ensinado a ler e escrever aos que não tiveram acesso à escola. Lembra também Santana, já neste século, a aula de música ministrada pelos músicos negros da banda municipal e, nos anos 50/60, a escola de teatro para negros. Basta reler tudo o que, neste artigo, falamos sobre a educação dos negros na antiga província de São Pedro do Rio Grande do Sul, para entender o que foi a missão do Floresta Aurora.

Entre 1984 e 1985, a referida Sociedade organizou dois grandes eventos: I e II Encontros Nacionais sobre a Realidade do Negro na Educação, para cuja organização contou com o apoio de Agentes de Pastoral Negros e Grupo de Negros do Partido Democrático Trabalhista do Rio Grande do Sul. Dos eventos participaram militantes, intelectuais e pesquisadores, convidados para proferir conferências e participar de debates, e um número significativo de professores da rede pública de ensino. Muitos dos participantes vinham de outros estados, especialmente de Santa Catarina, São Paulo, Rio de Janeiro e Bahia (Santana, 1985).

Nos registros dos eventos, destacam-se conferências versando sobre os temas: a) "a construção positiva da identidade da criança negra", b) "a auto-estima de crianças e jovens negros", c) "o teatro como veículo de educação da população negra”, d) "a evangelização do negro no período colonial”, e) "a presença/ausência da influência da formação escolar entre operários negros no pós-abolição". Tais temas foram tratados respectivamente pelos seguintes conferencistas: Iara Deodoro, Marilene Paré, Henrique Cunha Jr, Manoel de Lima Mira e Petronilha B. G. e Silva. Dos encontros participaram ainda representantes dos grupos de afoxé de Salvador, Olodum e o Ilê Ayê, trazendo suas experiências enquanto lugares de cultura, educação e religiosidade (Silva, 1990a).

A repercussão desses encontros para a auto-estima e confiança da população negra gaúcha foi percebida na transformação das práticas pedagógicas de algumas instituições.

Foi possível, após os eventos, criar projetos visando a introdução de temas de cultura e história dos negros nos programas escolares, embora ainda se consti- 
tuíssem como experiências individuais de professores militantes em suas salas de aula. Mas houve, também, iniciativas advindas do próprio sistema de ensino. A Secretaria Municipal de Santa Cruz do Sul, por força de lei municipal, instituiu o ensino de História do Negro nas escolas municipais, e o poder municipal criou a Semana de Consciência Negra. Estas iniciativas de grupos do movimento negro em todo o estado, atraem a atenção da Secretaria de Educação do Estado do Rio Grande do Sul que, ao lado de outros programas dirigidos a grupos marginalizados, cria o Projeto Negro e Educação. Este passa a promover atividades de divulgação de história e cultura negras, a estimular, junto aos orientadores educacionais, ações que visam à auto-estima de alunos negros e ao seu rendimento escolar (Triumpho \& Silva, 1999). Resultados a longo prazo destas iniciativas encontram-se registrados na obra organizada pela militante Vera Triumpho - Rio Grande do Sul aspectos da negritude (1990), bem como em algumas teses e dissertações que começam a ser elaboradas.

O primeiro evento no qual se fez um balanço da produção teórica sobre o tema Raça Negra e Educação foi organizado em 1986 pela Fundação Carlos Chagas, sob encomenda do Conselho de Desenvolvimento e Participação de Comunidade Negra do Estado de São Paulo, e com financiamento da Fundação Ford.

Foi um encontro político-acadêmico, pois não se limitou às pesquisas puramente acadêmicas. Nele, apresentaram-se experiências de políticas públicas e de ação educativa comunitária (Cadernos de Pesquisa, 1987). Deste evento, participaram, além de pesquisadores vinculados às universidades brasileira, educadores comunitários, técnicos e assessores das secretarias de educação. Puderam ser ouvidas as experiências desenvolvidas pelos grupos afro-baianos, como também aquelas, anteriormente mencionadas, em que os técnicos da Secretaria atuam junto de educadores comunitários, como estava ocorrendo, na época, na cidade do Rio de Janeiro.

Infelizmente não temos ainda dados disponíveis que permitam avaliar o papel desses assessores no que se refere à influência do seu trabalho na elaboração de políticas educacionais. O único trabalho de que temos conhecimento, que resultou em uma avaliação séria desse movimento interno na administração pública, é o de
Rachel de Oliveira. Membro do Conselho de Desenvolvimento e Participação da Comunidade Negra do Estado de São Paulo, a autora atuou diretamente na Secretaria de Educação, assessorando as equipes técnicas nas questões curriculares e de produção de material didático. Em seu estudo sobre esta experiência, ela analisa, de forma surpreendente, como o grupo que tinha a responsabilidade de cuidar da questão racial era isolado no interior da própria administração, fazendo com que suas ações ficassem fragmentadas e fossem tratadas como algo pontual, sem conexão com o resto. Em suma, a autora mostra o quanto de resistências internas o grupo teve de enfrentar no período em que atuou como assessora para assuntos da comunidade negra, na educação (Oliveira, 1987).

Em 1987, entidades negras de Brasília pressionaram a Fundação de Assistência ao Estudante (FAE) para que fossem adotadas medidas eficazes de combate ao racismo no livro didático. A FAE, por intermédio da Diretoria do Programa Nacional do Livro Didático (PNLD) convidou representantes de organizações negras de todo país para participar de um evento no qual se fez um balanço dos problemas de discriminação que afetam o livro didático. Do evento participaram todos os técnicos das Secretarias Estaduais de Educação envolvidos no PNLD. Na ocasião, militantes, técnicos e pesquisadores avaliaram a importância da medida, uma vez que a FAE fazia circular nos sistemas de ensino em torno de 60 milhões de livros didáticos. ${ }^{9}$

O debate sobre os negros e a educação aumentou em 1988, com o Centenário da Abolição. Desenvolveram-se nas diferentes regiões e estados múltiplos eventos que punham em discussão a problemática da educação dos negros. Dentre eles destacamos o Encontro do Movimento Negro do Sul e Sudeste no Rio de Janeiro, na Baixada Fluminense. Ali se discutiram, de forma muito articulada, as relações entre negros. Os militantes encaminharam propostas visando a capacitação profissional, que deviam ser levadas para serem discutidas nos sindicatos, entendendo-se que estes funcionariam como agência educativa de formação de trabalhadores

\footnotetext{
${ }^{9}$ Quanto aos resultados desse encontro, cf. Mello \& Coelho (1988).
} 
(Relatório Sul-Sudeste). Temos poucas informações dos desdobramentos dessas medidas. Como já dissemos, as entidades têm muita dificuldade de registrar suas ações e, quando o fazem, nem sempre conservam os registros nos arquivos das associações. Estes, muitas vezes, permanecem na casa dos militantes e se perdem.

Em todo caso, o M.N.U., seção Minas Gerais, tentou, sem muito sucesso, envolver alguns sindicatos na questão da formação profissional dos negros. Houve muita dificuldade, pois, no registro de uma das reuniões com sindicalistas, consta que a proposta foi descartada sob a alegação de que a discussão do racismo dividia a classe operária (Relatório M.N.U., Seção Minas Gerais).

Outros registros do M.N.U., Seção Minas Gerais, mostram o esforço dos militantes para criar uma escola de formação de quadros. Várias reuniões foram feitas para pensar estratégias de levantamento de fundos para a construção de uma sede, onde funcionaria a referida escola. Há ainda o registro de uma doação, em dinheiro, ao M.N.U. mineiro, advinda de uma ex-militante, que se mudou para a Alemanha. O recurso foi doado com a condição de que ele revertesse para uma escola de formação de quadros. O que se sabe é que esta escola nunca foi criada. Mas, mesmo assim, houve uma tentativa de ministrar cursos aos militantes, através de um acordo com setores da Universidade Federal de Minas Gerais. O curso foi realizado, entre 1989 e 1990, mas não encontramos nenhuma avaliação do mesmo.

Para finalizar o presente artigo, falaremos do VIII Encontro dos Negros do Norte e Nordeste. Este evento foi integralmente dedicado a questões educacionais que afetam o negro brasileiro.

Tendo Recife como sede do evento, os militantes puderam fazer um diagnóstico da situação educacional precária dos afrodescendentes. Mais do que nunca entendiam que os 100 anos de abolição, para os negros, tinha significado muito pouco em termos de garantia de direitos constitucionais.

Manejando dados estatísticos, a militante Sueli Carneiro examinou o peso da desigualdade em nossa sociedade. Segundo ela, é na educação que as desigualdades são mais fortes. "É ali onde as diferenças entre nós e as mulheres de outras etnias se tornam mais nítidas" (Carneiro, 1988, p. 39). A taxa de analfabetismo atingia mais as negras e, ainda, elas eram minoria nas universidades. Segundo os dados apresentados por Sueli Carneiro, 48\% das negras não conseguiam, em 1988, concluir um ano de estudo, enquanto que, entre as mulheres brancas, esta porcentagem caía para $24 \%$ (idem).

A persistência dessas taxas, associada aos mecanismos sociais de depreciação através dos quais as mulheres negras e mestiças desenvolvem um poderoso sentimento de inferioridade, acaba por criar um quadro dramático que implica toda uma geração de crianças e jovens (Gonçalves, 1997, p. 495). Veja-se, por exemplo, o relato de Valdeci Pereira, uma militante negra de Salvador: "Nós, mulheres negras, militantes de movimentos [...] vivemos ainda em função da educação que nos é reservada [...] O homem crê ter o direito de abandonar a família. Quando não suporta a pressão econômica, fica louco. Mas as mulheres nem este direito têm. É ela que tem de assumir totalmente a situação, é dela que depende toda a nova geração. Ela não tem orientação a seguir para formar as crianças e jovens. Como pode educar as meninas e os meninos tendo uma outra perspectiva de futuro, se ela também é um produto desta sociedade racista?" (Pereira, 1988, p. 41).

Tendo em vista a dimensão do problema, podemos entender por que, no VIII Encontro de Negros do Norte e Nordeste, o clima do debate foi dominado por uma postura feminista. "O feminismo negro transformou", naquele evento, "a educação em um campo privilegiado de reivindicações e de luta” (Gonçalves, 1997, p. 496).

As militantes sabiam que não poderiam contar com a escola para ajudá-las numa educação não racista, pois "a instituição escolar também era um instrumento de propagação da supremacia racial branca" (idem). ${ }^{10}$

Veja-se, por exemplo, como a militante Sueli Carneiro refletia sobre a questão escolar: "Não basta reivindicar o acesso à escola, é preciso também um controle sobre a qualidade do ensino que nos oferecem. Este controle não estava ainda completamente definido, no nosso programa de ação, porque o movimento de mulheres negras é um evento recente. Mas essa questão se

${ }^{10}$ Sobre esse assunto, ver ainda Gonçalves, 1985, e Rosemberg, 1987. 
supõe como uma bandeira para as lutas fundamentais de nossa organização" (Carneiro, 1988, p. 46).

Em todo caso, é preciso registrar que o grande aliado do movimento de mulheres negras, no combate aos preconceitos na educação, foi o movimento de docentes das escolas públicas (no qual há uma predominância feminina), que teve uma atuação muito vigorosa nos anos 80. "Na medida em que o movimento negro se engajou nas lutas pela valorização da escola pública, ele pôde sensibilizar o setor educacional na defesa de suas reivindicações contra o racismo" (Gonçalves, 1997, p. 499).

O movimento negro passou, assim, praticamente a década de 80 inteira, envolvido com as questões da democratização do ensino. Podemos dividir a década em duas fases. Na primeira, as organizações se mobilizaram para denunciar o racismo e a ideologia escolar dominante. Vários foram os alvos de ataque: livro didático, currículo, formação dos professores etc. Na segunda fase, as entidades vão substituindo aos poucos a denúncia pela ação concreta. Esta postura adentra a década de 90.

Já em 1994, vamos encontrar experiências muito interessantes envolvendo entidades negras e Secretarias de Educação em uma relação produtiva. O exemplo desse envolvimento é o trabalho que vem sendo realizado pelo Núcleo de Estudos do Negro, NEN, com financiamento da Fundação Ford. Têm sido realizados vários seminários organizados por esse Núcleo, com a participação de professores do ensino fundamental do Estado de Santa Catarina, estendendo-se também aos outros estados da Região Sul. Há três anos ininterruptos o Núcleo tem publicado um caderno trimestral de pesquisas educacionais tratando do tema do negro e a educação: a série Pensamento Negro e Educação. Estas publicações de certa forma buscam responder a preocupações, ideais, propostas como os manifestados e debatidos no seminário sobre Pensamentos Negros em Educação - Expressões do Movimento Negro, realizado pelo Núcleo de Estudos Afro-Brasileiros da Universidade Federal de São Carlos em 1995, e que resultou em publicação com o mesmo título organizada por Silva \& Barbosa (1997).

Experiência similar vem ocorrendo em Salvador. O Centro de Estudos Afro-Orientais, CEAO, com apoio da Universidade Federal e da Universidade Estadual da
Bahia, tem organizado encontros com professores de ensino fundamental. Aliás, ali a experiência é sistemática. Existem cursos de capacitação de professores para lidar com o tema da diversidade cultural.

Já em São Paulo o Núcleo de Estudos Afro-Brasileiros da UFSCar, em colaboração com diretorias de ensino e prefeituras municipais, vem desenvolvendo cursos para professores da rede pública de ensino sobre direitos humanos e combate ao racismo.

Poderíamos multiplicar os exemplos, pois esses cursos têm sido realizados em Curitiba, Brasília, Rio de Janeiro, São Paulo, Belo Horizonte e outras capitais e cidades do país. Mas o que é importante ressaltar é que esses encontros marcam uma nova relação entre os movimentos negros e a esfera pública. Hoje, mais do que nunca, compreende-se que as organizações não-governamentais têm tido um papel fundamental em ações educativas que visam melhorar a auto-estima de crianças e jovens negros. Exemplos dessas ações são os projetos desenvolvidos pela Escola de Samba Estação Primeira de Mangueira, no Rio de Janeiro, e pelos afoxés Ilê Ayê, Araketo, Olodum, em Salvador.

Como se pode ver, quando se trata de descobrir estratégias que auxiliem no desenvolvimento educacional dos negros, não há necessidade de afastá-los de suas atividades de lazer e recreativas.

Por paradoxal que seja, o tema da diversidade, embora apareça na década de 90, é antigo. Aliás, como mostramos no início deste artigo, ele acompanha a história da inserção dos negros na moderna sociedade brasileira. Ele evoluiu e amadureceu à medida que os setores sociais que dele dependiam para expressar seus medos, angústias e projetos, o trouxeram ao debate público.

Ora, o tema da diversidade cultural acabou trazendo também para os movimentos negros (em seu sentido clássico) um novo problema: como lidar com a diversidade no interior do próprio movimento?

Este desafio já foi vivido quando se criou, no interior dos movimentos, uma corrente que marcava a presença das mulheres negras em uma situação bastante diferenciada (Silva, 1990 e 1998; Gonçalves, 1997).

Agora, são os jovens que trazem a marca de seus próprios movimentos, de seus grupos de estilo: hip-hop, 
funk e outros. Estudos têm mostrado o quanto estes grupos têm servido para desenvolver nos jovens o espírito crítico, ajudando-os a fazer uma leitura mais criativa do mundo (Spósito, 1994; Gomes, 1999; Candau, 2000).

Entretanto, esses jovens continuam defasados e, muitos, excluídos do sistema de ensino regular. Enfim, este continua sendo um problema crucial para a educação dos negros no Brasil, um velho problema.

Isto explica por que os movimentos negros, embora convencidos da importância dos grupos de estilos, continuam a reivindicar educação escolar para todos. O problema que se nos coloca é como combinar as duas estratégias educativas.

De sobra, resta, ainda, o enfrentamento de uma discussão espinhosa: o acesso à universidade.

Os anos 90, com seus traços multiculturais e interculturais, fizeram-nos pensar em um problema que poucos acreditavam que um dia pudéssemos discutir. Parecia coisa de estadunidenses. Mas não é. Afinal de contas como aumentar o índice de estudantes negros na universidade?

Algumas experiência têm sido tentadas, como, por exemplo, os pré-vestibulares para pobres e negros. Algumas propostas têm sido feitas: ações afirmativas, sistemas de cotas (USP, 1996; Silva, 1999b). Enfim, sobre esta história pouco temos a contar. Tudo está por ser feito. Neste sentido, só nos cabe duas coisas: participar e nos envolver de corpo e alma nesses eventos tão palpitantes de nossos tempos.

LUIZ ALBERTO OLIVEIRA GONÇALVES é doutor em sociologia e professor adjunto da Universidade Federal de Minas Gerais. Entre suas publicações destacam-se: Le Mouvement noir au Brésil. (Lille, Presses Universitaires Septentrion, 1997).

E-mail: laog@fal.ufmg.br

PETRONILHA BEATRIZ GONÇALVES E SILVA é doutora em Ciências Humanas, área de educação e professora adjunta docente da Universidade Federal de São Carlos. Publicou História de Operários Negros (Porto Alegre, EST, Nova Dimensão, 1987).

E-mail: dpbs@power.ufscar.br

Os dois autores publicaram em conjunto: O Jogo das Diferenças: multiculturalismo e seus contextos (2. ed., Belo Horizonte, Autêntica, 2000).

\section{ReferênciasBibliográficas}

AGUIAR, J., (1928). O negro no Brasil. Clarim d'Alvorada, São Paulo, v. 1, no 5, p. 1, 3 jun.

(1929). A liberdade. Clarim d'Alvorada, São Paulo, v. $6, n^{\circ} 16$, p. 1,13 maio.

ALMEIDA, J. R. P. de, (2000). Instrução pública no Brasil (15001889) - história e legislação. 2. ed. rev. São Paulo: Ed. da PUC/ SP. Ed. crítica Maria do Carmo Guedes. Trad. Antônio Chizzotti.

CUNHA, Antunes, (1930). O negro deve se prevenir. Clarim d'Alvorada, São Paulo, v. 8, nº 31, p. 1, 7 dez. (1991). Notas de uma entrevista. São Paulo. (Datilografado)

, (2000). Imprensa negra e educação. São Paulo (Anotações para um texto).

AZEVEDO, C. M. M., (1993). Onda negra, medo branco : o negro no imaginário das elites - século XX. Rio de Janeiro: Paz e Terra.

BARBOSA, M., et al., (1998). Frente Negra: Depoimentos. São Paulo: Quilombo Hoje.

BARCELOS, L. C., (1992). Raça e realização educacional no Brasil. Dissertação de Mestrado, Rio de Janeiro: IUPERJ.

BATHO, A., (1930). Educação (especial para o Clarim d'Alvorada). Clarim d'Alvorada, São Paulo, v. VII, nº 26, p. 2, 13 maio.

BEISIEGEL, C. R., (1974). Estado e educação popular : um estudo sobre a educação de adultos. São Paulo: Pioneira.

CANDAU, V., (org.), (2000). Reinventar a escola. Petrópolis: Vozes.

CARNEIRO, S., (1988). Depoimento. VIII Encontro dos Negros do Norte e Nordeste. Recife.

CADERNOS DE PESQUISA, (1987). Especial sobre "Raça Negra e Educação". São Paulo: Fundação Carlos Chagas, nº 63.

CADERNOS DE EDUCAÇÃO COMUNITÁRIA, (1983). Belo Horizonte, v. $1, \mathrm{n}^{\circ} 2$, p. 16-23.

CHALHOUB, S., (1988). Medo branco de almas negras: escravos, libertos e republicanos na cidade do Rio. Revista Brasileira de História, São Paulo, v. 8, n 16, mar./ago.

COSTA, A., (1930). Clarim d'Alvorada, São Paulo, v. 8, nº 31, p. 4, 7, dez.

CUTI \& CORREIA LEITE, (1992). E disse o velho militante. Depoimentos e artigos. São Paulo: Secretaria Municipal de Cultura. 
DANTAS, B. G., (1995). De feiticeiros a comunistas; acusações sobre o Candomblé. Dédalo, n 23, São Paulo, p. 35-48.

FERNANDES, F., (1986). A integração do negro na sociedade de classe. São Paulo: Ática, v. 2.

FERREIRA, A. \& BITTAR, M., (2000). Educação jesuítica e crianças negras no Brasil colonial. São Carlos.

FONSECA, M. V., (2000). Concepções e práticas em relação à educação dos negros no processo de abolição do trabalho escravo no Brasil (1867-1889). Dissertação de Mestrado. Belo Horizonte: UFMG.

FUNDAÇÃO CARLOS CHAGAS, (1987). Cadernos de Pesquisa, São Paulo, n 63 , nov.

GAMA, L., (1935). Carta ao Filho. O Clarim, São Paulo, v. 1, nº 4, p. 1, maio.

GOMES, N. L., (1999). Rapps educação e identidade racial. In: LIMA, Ivan C., et al. Educação popular afro-brasileira. Florianópolis: NEN - Núcleo Estudo do Negro, p. 73-91.

GONÇALVES, L. A., (1997). Le mouvement noir au Brésil. Lille: Presses Universitaires du Septentrion.

, (1985). O silêncio : um ritual pedagógico a favor da discriminação racial. Um estudo acerca da discriminação racial nas escolas públicas. Dissertação de Mestrado. Belo Horizonte: UFMG.

, (2000). Negros e educação no Brasil. In: LOPES, E. M. et al. 500 anos de Educação no Brasil. Belo Horizonte: Autêntica, p. 325-346.

, (1999). As políticas públicas como instrumento de reversão das desigualdades étnicas nos sistemas de ensino. Belo Horizonte: UFMG.

GONÇALVES, L. A \& SILVA, P. B. G. E., (1998). O jogo das diferenças : o multiculturalismo e seus contextos. Belo Horizonte: $\mathrm{Au}-$ têntica.

GUERREIRO RAMOS, (1966). O negro no Brasil: um exame de consciência. In: TEN - Testemunhos, Rio de Janeiro: GRD.

HASENBALG, C., (1979). Discriminação e desigualdades raciais no Brasil. Rio de Janeiro: Graal.

LARKIM NASCIMENTO, E. L. do, (1981). Pan-africanismo na América do Sul : emergência de uma rebelião negra. Petrópolis: Vozes.

LEITE, J. C., (1978). A alvorada de uma luta - entrevista a Rui Veiga. Folhetim, São Paulo, p. 9, 14 de maio.
MARCILLIO, M. L., (1997). A roda dos expostos e a criança abandonada na história do Brasil. In: FREITAS, M. C. de, (org.). História social da infância no Brasil. São Paulo: Cortez.

MATTOSO, K. de Q., (1988). O filho da escrava. Revista Brasileira de História, vol. 8, n 16, São Paulo, p. 37-56.

MELO, R. L. C. de \& COELHO, R. de C. F., (1988). Educação e Discriminação dos negros. Belo Horizonte: Instituto de Recursos Humanos João Pinheiro.

MOACYR, P., (1939). A Instrução e as províncias : subsídios para a história da educação no Brasil (1834-1889). São Paulo: Companhia Editora Nacional.

MOTT, M. L. et al., (1988). A escravidão e a criança negra. In: Negros Brasileiros, Ciência Hoje. Brasília: CNPq, Suplemento, v. 8, nº 48.

MOURA, C., (1983). Brasil - Raízes do protesto negro, São Paulo: Globo.

, (s/d). A imprensa negra em São Paulo, mimeo.

NASCIMENTO, A., (1940). Influência da mulher negra na educação do brasileiro. In: O negro no Brasil - trabalhos apresentados no $2^{\circ}$ Congresso Afro-Brasileiro. Rio de Janeiro: Civilização Brasileira, p. 211-222.

., (1978). Genocídio do negro brasileiro: processo de um racismo mascarado. Rio de Janeiro: Paz e Terra.

NASCIMENTO, M. E. do., (1989). A estratégia da desigualdade: o movimento negro dos anos 70. Dissertação de Mestrado. São Paulo: PUC/SP.

OLIVEIRA, R., (1987). Reflexões sobre a experiência de alterações curriculares em São Paulo. Cadernos de Pesquisa, São Paulo: Fundação Carlos Chagas, ${ }^{\circ} 63$.

PAIVA, V., (1987). Educação popular e educação de adultos. 5 ed. São Paulo: Loyola.

PERDIGÃO MALHEIROS., (1976). A escravidão no Brasil: ensaio político, jurídico e social. 3. ed. Petrópolis: Vozes, INL, [1867], v. I.

PEREIRA, V., (1988) Mulher negra e educação. VIII Encontro do Negro do Norte e Nordeste. Recife.

PERES, E. T., (1995). “Tempo da Luz”, os cursos noturnos masculinos de instrução primária da biblioteca pelotense (1875-1915). Dissertação de Mestrado. Porto Alegre: UFRGS.

PINTO, N. de S., (1924). A desanalfabetização. Getulino, v. 2, nº 64, $20 \mathrm{dez}$. 
PINTO, R. P. A., (1994). Movimento negro em São Paulo: luta e identidade. Tese de Doutorado, São Paulo: FFCH/USP.

RELATÓRIO M.N.U., (1998). Preparação do Centenário de Zumbi, Seção Minas Gerais.

RIZZOLI, Á., (1995). A escravidão em São Carlos : inventário analítico. São Carlos: Universidade Federal de São Carlos, Núcleo de Estudos Afro-Brasileiros.

ROSEMBERG, F. et al., (1987). Diagnóstico da situação educacional de negros (pretos e pardos) no Estado de São Paulo. São Paulo: Fundação Carlos Chagas/Conselho de Participação da Comunidade Negra.

SANTANA, N., (1985). Relatórios do I e II Encontro sobre Realidade do Negro na Educação. Porto Alegre: mimeo.

SCHWARCZ, L., (1987). Retrato em branco e negro: jornais, escravos e cidadãos em São Paulo no final do século XIX. São Paulo: Companhia das Letras.

SILVA, J. C. da., (1988). História de lutas negras: memórias do surgimento do movimento negro na Bahia. In: M. N. U., 1978-1988, 10 Anos de Luta contra o Racismo. São Paulo: Confraria do Livro.

SILVA, P. B. G. e, (1987). Histórias de operários negros. Porto Alegre: EST, Nova Dimensão.

, (1998). "Chegou a hora de dar à luz a nós mesmas" Situando-nos enquanto mulheres e negras. Cadernos CEDES, Campinas, $\mathrm{n}^{\circ} 45$, p. 7-23.

(1990). Organizações das mulheres negras, hoje. Revista de Cultura Vozes, Petrópolis, v. 84, nº 2, p. 220-226, mar./abr. , (1999a). Movimento negro, educação e produção do conhecimento de interesse dos afro-brasileiros. Educação, Porto Alegre: PUC/RS, v. 22, nº 39, p. 27-40, set.

(1999b). Direitos X Privilégios - Eis a questão das ações afirmativas. São Carlos/SP (Palestra proferida em Seminário Organizado pelo Instituto de Estudos Avançados da USP, na USP/São Carlos).

SILVA, P. B. G. e \& GOLÇALVES, L.A., (1998). O jogo das diferenças : o multiculturalismo e seus contextos. Belo Horizonte: Autêntica.

SILVA, P. B. G. e \& BARBOSA, L. M. de A., (1997). Pensamentos Negros em Educação: expressões do Movimento Negro. São Carlos: Ed. da Universidade Federal de São Carlos.
SILVA, P. B. G. e \& BERNARDES, N. M. G., (1988). Relatório. Porto Alegre, datilografado.

SPÓSITO, M. P., (1994). A sociabilidade juvenil e a rua: novos conflitos a ação coletiva na cidade. Tempo Social, São Paulo, v. 5, $\mathrm{n}^{\circ} 1$ e 2, p. 161-178, nov.

TRIUMPHO, V. R. S., (org), (1991). Rio Grande do Sul - aspectos da negritude. Porto Alegre: Martins Livreiro.

TRIUMPHO, V. R. S. \& SILVA, P. B. G. E., (1999b). Construindo Práticas Educativas: a experiência dos agentes de Pastoral Negro no Rio Grande do Sul. In: LIMA, Ivan C. et al. Educação popular afro-brasileira. Florianópolis. NEN - Núcleo de Estudo do Negro, p. 113-116.

USP - Grupo de Políticas Públicas, (1996). Documento: uma jornada pela justiça. In: MUNANGA, Kabengele. Estratégias e políticas de combate à discriminação racial. São Paulo: EDUSP, p. 265-293.

VICENTE, J., (1988). Movimento negro em Pernambuco. VIII Encontro dos Negros do Norte e Nordeste. Recife.

Literatura Militante

O Clarim d'Alvorada - 24/10/1926

O Clarim d'Alvorada - 07/04/1929

O Clarim d'Alvorada - 09/06/1929

O Clarim d'Alvorada - 1930

O Clarim d'Alvorada - 1935

O Alvorada - 1936

O Progresso - 26/09/1929

O Progresso - 28/09/1930

O Getulino - 1924

A Voz da Raça-25/03/1933

A Voz da Raça - 08/07/1933

A Voz da Raça - 17/02/1934

A Voz da Raça - 23/06/1934

Quilombo, $\mathrm{n}^{\text {os }} 5$ e 6

Programa de Ação do Movimento Negro Unificado - 1982

VIII Encontro de Negros Norte e Nordeste - 1988

Relatório das Entidades Negras de Belo Horizonte - 1988 